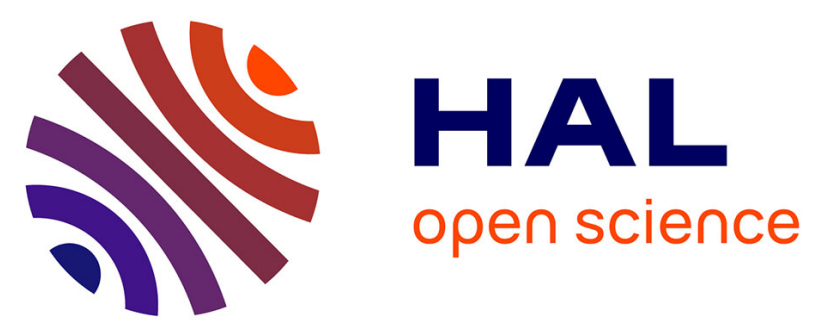

\title{
Pesticide-induced oxidative stress in laboratory and field populations of native honey bees along intensive agricultural landscapes in two Eastern Indian states
}

Priyadarshini Chakrabarti, Santanu Rana, Sagartirtha Sarkar, Barbara Smith, Parthiba Basu

\section{To cite this version:}

Priyadarshini Chakrabarti, Santanu Rana, Sagartirtha Sarkar, Barbara Smith, Parthiba Basu. Pesticide-induced oxidative stress in laboratory and field populations of native honey bees along intensive agricultural landscapes in two Eastern Indian states. Apidologie, 2015, 46 (1), pp.107-129. $10.1007 / \mathrm{s} 13592-014-0308-\mathrm{z}$. hal-01284428

\section{HAL Id: hal-01284428 \\ https://hal.science/hal-01284428}

Submitted on 7 Mar 2016

HAL is a multi-disciplinary open access archive for the deposit and dissemination of scientific research documents, whether they are published or not. The documents may come from teaching and research institutions in France or abroad, or from public or private research centers.
L'archive ouverte pluridisciplinaire HAL, est destinée au dépôt et à la diffusion de documents scientifiques de niveau recherche, publiés ou non, émanant des établissements d'enseignement et de recherche français ou étrangers, des laboratoires publics ou privés. 


\title{
Pesticide-induced oxidative stress in laboratory and field populations of native honey bees along intensive agricultural landscapes in two Eastern Indian states
}

\author{
Priyadarshini Chakrabarti ${ }^{1,2}$, Santanu RANA ${ }^{1}$, Sagartirtha SARKar ${ }^{1}$, \\ Barbara $\mathrm{SMITH}^{2,3}$, Parthiba BASU ${ }^{1,2}$ \\ ${ }^{1}$ Department of Zoology, University of Calcutta, 35, B.C. Road, Kolkata 700019, India \\ ${ }^{2}$ Centre for Pollination Studies, University of Calcutta, 35, B.C. Road, Kolkata 700019, India \\ ${ }^{3}$ Game \& Wildlife Conservation Trust, Burgate Manor, Fordingbridge, Hampshire SP6 1EF, UK
}

Received 14 June 2013 - Revised 24 June 2014 - Accepted 9 July 2014

\begin{abstract}
Pesticides have been cited as one of the major drivers of pollinator loss. However, little is known about pesticide impacts on natural populations of native honey bee species. This study looked into the effect of pesticides with respect to oxidative stress in the laboratory and in field populations of two native Indian honey bee species (Apis dorsata and A. cerana) by examining a combination of biomarkers, e.g., superoxide dismutase, catalase and xanthine oxidase. A significant upregulation of all three biomarkers was observed in both treated individuals in laboratory experiments and field populations sampled from a pesticide use gradient. This study reports, for the first time, an increase in expression of xanthine oxidase in an invertebrate system (honey bees) exposed to pesticides.
\end{abstract}

Apis cerana / Apis dorsata / enzyme / super-oxide dismutase / catalase / xanthine oxidase / insecticide

\section{INTRODUCTION}

Pesticide use, apart from loss of natural vegetation cover (Winfree et al. 2009), has been cited as one of the major drivers of the recent decline in pollinator populations (Brittain et al. 2010; Mullin et al. 2010; Henry et al. 2012; Whitehorn et al. 2012). This assertion is underpinned by a number of studies that looked into the toxic impacts of various pesticides on Apis mellifera or bumble bees through dose or

Electronic supplementary material The online version of this article (doi:10.1007/s13592-014-0308-z) contains supplementary material, which is available to authorized users.

Corresponding author: P. Basu,

bparthib@gmail.com

Manuscript editor: Monique Gauthier exposure-mortality response relationships in controlled ecotoxicological experiments (Decourtye et al. 2004; Choudhary et al. 2009; Brittain et al. 2010; Johnson et al. 2010). Apart from dose mortality responses, a number of biomarkers, including fecundity (Cresswell and Laycock 2012; Henry et al. 2012), sub-lethal markers like proboscis extension response/reflex (Decourtye et al. 2005; Han et al. 2010) or homing behaviour (Henry et al. 2012) and physiological markers (Badiou-Bénéteau et al. 2012), have also been used to study the sensitivity of honey bees to pesticide exposure in controlled experiments. However, it should be noted that: a) little is known about the sensitivities of other native Apis bees apart from $A$. mellifera with respect to any of the biomarkers that have been used so far; and b) there is a large information gap on the response of 
naturally occurring native honey bee populations (wild populations of non-exotic species) to multiple pesticide exposure in field conditions (Osborne 2012). In view of this, a comparison of native bee species responses across a pesticide use gradient using combinations of biomarkers (Badiou-Bénéteau et al. 2012) would be a crucial and valuable contribution towards developing a more accurate pesticide regulatory framework. In the present study, we compare the sensitivity of two native Apis species of India in two kinds of agricultural landscapes with varying degrees of pesticide use.

Honey bees, like other insects, are reasonably sensitive to a range of chemical insecticides (Devillers et al. 2002; Stefanidou et al. 2003; Hardstone and Scott 2010), and bees close to agricultural areas are particularly vulnerable to pesticide exposure through multiple routes (Krupke et al. 2012). A number of physiological biomarkers of xenobiotics have been investigated in various animal species (Badiou-Bénéteau et al. 2012). However, acetylcholinesterase has been particularly prominent among the physiological markers for xenobiotics studies in honey bees, and as has been suggested, a combination of other different physiological response markers would provide a more precise diagnosis (Badiou-Bénéteau et al. 2012).

Pesticides are known to cause significant oxidative stress across a wide range of animal taxa including insects (Qiao et al. 2005). Oxidative stress occurs when production of reactive oxygen species (ROS) exceeds an organism's natural anti-oxidative defense mechanism (Velki et al. 2011; Nishida 2011), and such imbalance may result from an overabundance in ROS-producing stressors in the environment (Halliwell 2007).

Antioxidant enzymes such as superoxide dismutase (SOD) and catalase (CAT) are of vital importance in an organism's defense against oxidative stress (McCord and Fridovich 1969; Fridovich 1982; Khessiba et al. 2005; Schriever et al. 2008; Mamidala et al. 2011), and both have been associated with pesticide toxicity in insects (Landa et al. 1991), frogs (Czarniewska et al. 2003) and also in freshwater clams (Conners 2004). A number of antioxidant enzymes, such as SOD, CAT, glutathione $S$-transferase, glutathione peroxidase and glutathione reductase, have been reported to occur in insects (Ahmad et al. 1991; Felton and Summers 1995; Joanisse and Storey 1996). Increased levels of anti-oxidant enzymes would therefore be indicative of the organisms' attempt at coping in an oxidative stress environment.

Free radicals act on important macromolecular structures of the organism and can cause severe damage to the physiology of the organism by interfering with cell components, including proteins, lipids, and DNA (Akhgari et al. 2003; Ranjbar et al. 2005). Imbalance of free radicals within the body can affect processes like lipid peroxidation that are vital to the survival of an animal (Akhgari et al. 2003). Hence, elevated levels of CAT and SOD could be an adaptive response to this imbalanced scenario as a protective mechanism (Akhgari et al. 2003).

Honey bees may employ a range of mechanisms as defense against pesticides, and the biochemical route (altered target enzymes and differential levels of detoxification enzymes) is a major mechanism for this (Smirle 1988). Honey bees are known to have an active detoxification system (Gilbert and Wilkinson 1974; Yu et al. 1984; Smirle 1988). Unlike younger workers, who mainly perform housekeeping tasks inside the colony, various mixed function oxidases get activated in older forager workers, and it has been suggested that this is a biochemical adaptation against environmental toxins such as pesticides and plant allelochemicals (Smirle and Winston 1988). An elevated level of antioxidant enzyme activities is, therefore, a potential biomarker for oxidative stress for honey bees in pesticide-laden environments.

Under normal conditions, xanthine oxidase (XOX) predominantly exists in an organism in the form of xanthine dehydrogenase (XDH), which under oxidative stress is converted to XOX (Wajner and Harkness 1989; Vorbach et al. 2003; Nishino et al. 2005; Zhang et al. 2010). XDH is frequently found in insects 
(Irzykiewicz 1955; Anderson and Patton 1955; Hayashi 1961; Vorbach et al. 2003), and its conversion to XOX has also been previously reported in this taxon (Joanisse and Storey 1996). The enzyme XOX not only performs various cellular protective functions crucial to innate immune systems, but it also contributes to the synthesis of numerous ROS and reactive nitrogen species (Hille and Nishino 1995; Harrison 2002; Meneshian and Bulkley 2002). Xanthine oxidase, a form of the enzyme xanthine oxido-reductase (Vorbach et al. 2003), has been identified as an evolutionarily conserved housekeeping enzyme (Vorbach et al. 2003). Enhanced levels of serum XOX activity for pesticide stress have been already reported in humans (Zhang et al. 2010). There has been no previous research showing a change in XOX expression as a result of pesticide-induced stress in insects. However, as evident from literature cited above, there is sufficient reason to suggest that the anti-oxidant enzymes, along with XOX, could be treated as important markers for pesticide-induced physiological stress.

One fundamental requirement for a foraging bee's survival is its ability to explore the surroundings and return back to the hive. If pesticides known to cause oxidative stress (Badiou-Bénéteau et al. 2012) begin to impede homing and foraging success in a forager (Henry et al. 2012), then the role of antioxidant enzymes in counteracting such (pesticide-induced) stress would become critical. Investigating $\mathrm{XOX}, \mathrm{CAT}$ and $\mathrm{SOD}$ as an effective biomarker combination for such stress could help establish if a natural population of bees foraging in a pesticide-intensive agricultural area is under severe oxidative stress. Longterm exposure to sublethal treatments may also pose a major threat to hive proliferation and survival of bees (Desneux et al. 2007).

We checked if pesticide exposure brings about any change in the SOD, CAT and XOX levels in honey bees. We hypothesized that these markers would be differentially regulated in honey bees exposed to graded treatments of pesticides in the laboratory that are also used in the agricultural landscape. We also hypothe- sized that natural honey bee populations in areas of intensive agriculture, and therefore in areas with high levels of pesticide applications, would show increased activities of both XOX and antioxidant enzymes, e.g., SOD and CAT, compared to areas with low intensity agriculture (and lower levels of pesticide consumption).

We tested the above hypothesis using a controlled laboratory experiment to assess if exposures to varying treatments of pesticides that are used in the agricultural landscapes bring about any change in the activity levels of antioxidant enzymes and XOX in two species of honey bees ( $A$. dorsata and A. cerana). We followed this assessment with a comparative estimation of the activity levels of the same enzymes in honey bees collected from our chosen agricultural landscapes, comprising both non-agricultural or forest areas as well as intensive cropping areas.

\section{METHODS}

\subsection{Agricultural intensification landscapes}

Two agricultural landscapes were chosen. One was located in the state of West Bengal and the other in the state of Odisha. In each landscape, two locations were chosen to represent high intensity cropping (HIC) and low intensity cropping (LIC) areas based on the cropping intensity (which is expressed as gross cropped area divided by net sown area) and pesticide residue in soil. For West Bengal, the LIC site was chosen to be adjacent to the Sunderban Biosphere Reserve, where cropping is limited to small patches of home gardens. Similarly, the LIC in Odisha was chosen to be near Kuldiha Wildlife Sanctuary, where farming is restricted to subsistence home gardens. HIC areas in both West Bengal and Odisha predominantly have large-scale vegetable cultivation interspersed with paddy fields (Supplementary Table 1). Both of the HIC areas are the vegetable production hubs in their respective states. Cropping intensity was provided by the respective Departments of Agriculture for the Governments of Odisha and West Bengal. 


\subsection{Pesticide residue analyses}

Soil pesticide residue was measured by liquid chromatography-mass spectrometry/mass spectrometry (LC-MS/MS) and gas chromatography (GC), following EPA3540C and EPA8081A procedures having a detection limit of $0.1 \mathrm{mg} \mathrm{kg}^{-1}$ at facilities provided by SGS India Private Limited. Pesticide use by farmers in each locality was assessed by conducting group appraisal surveys (Figure 1a). All the soil samples were seasonally matched.

Pesticide residues from honey bees were measured from random samples of honey bees collected from different study sites (Figure 3a, b). Pesticide analysis was also done at facilities provided by SGS India Private Limited.

\subsection{Sampling honey bees}

Random samples of individual $A$. dorsata and $A$. cerana foragers were collected at the entrance of nests. Wild populations of $A$. dorsata individuals were collected from a total of eight nests (three in West Bengal and five in Odisha). For A. cerana, individuals were collected from a total of eight colonies, of which two were managed colonies in bee boxes due to paucity of natural nests. Individuals from the managed colonies foraged freely from the natural surroundings. A. cerana samples were obtained only from Odisha, as they are not commonly found in our chosen landscape sites in West Bengal. Honey bee samples were also seasonally matched. We refer to Apis dorsata sampled from HIC and LIC in West Bengal as AD and SD, respectively, and A. dorsata sampled from HIC and LIC in Odisha as JD and PD, respectively, as shown in Figure 7a, b. Apis cerana sampled from HIC and LIC in Odisha are referred to as JC and PC, respectively (Figure 7c, d). A flow chart of the experimental design has been provided in the supplementary material (Supplementary Figure 2).

\subsection{Feeding honeybees with pesticides in laboratory experiments}

Individual A. cerana colonies brought from LIC zones were maintained in separate cages, where they were acclimatized for 2 days and fed sugar syrup (3 molar) and dry multi-floral pollen [procured from $\mathrm{M} / \mathrm{S}$
Ambrosia Natural Products (India) Pvt. Ltd.]. Thirty individuals from each colony were placed in smaller experimental cages, where they were fed with $6 \mathrm{~mL}$ sugar syrup (three 2-mL feeder tubes) treated with varying concentrations of pesticides, with an exposure time of $6 \mathrm{~h}$. For every experiment, there was a control cage where the bees were fed with similar volumes of sugar water without the pesticides. Since our principal focus was field populations, treatments were selected using concentrations known to be used by farmers in the field. The treatments selected included a gradient of concentrations with values lower and higher than the typical field applications, and each treatment was checked for sub-lethality through a treatment-response experiment. The pesticides used by farmers, and which were also found in soil and honey bee whole-body pesticide residue analyses, were procured from local pesticide outlets. The bees were starved overnight before the experiment.

As it is not possible to rear A. dorsata in bee boxes, live individuals were brought from LIC zones and acclimatized in cages for 2 days before exposure to pesticides. The experimental cages were kept outdoors to simulate near-field environmental conditions. During acclimatization, the bees were fed with 3 molar sugar syrup ad libitum for $6 \mathrm{~h}$.

For A. dorsata, we treated 20 individuals in smaller cages with similar combination of pesticides in $4 \mathrm{~mL}$ sugar syrup (two 2-mL feeder tubes) for $6 \mathrm{~h}$. For both the species, we had six replicates for each treatment. For each replicate, the volume of the contaminated solution that remained in the feeding tubes was checked at the end of the contamination period of $6 \mathrm{~h}$.

Three pesticide formulations were used in combination: an organophosphorus (OP) pesticide - dimethoate, $30 \%$ effective concentration (EC) (Tagfor, Rallis India Limited, Akola, Maharashtra); a synthetic pyrethroid (SP)—cypermethrin, $10 \%$ EC (Ustaad, United Phosphorus Limited, Vapi, Gujarat); and an organochlorine pesticide (ES) - endosulfan, $35 \%$ EC (Thiodan, Bayer, Ankleshwar, Gujarat).

The field use pattern of all three pesticides is $15 \%$ $\mathrm{OP}+5 \% \mathrm{SP}+17.5 \% \mathrm{ES}$ in HIC sites of West Bengal and Odisha. For the LIC site in West Bengal, the field use pattern of pesticides is $8 \% \mathrm{SP}+17.5 \% \mathrm{ES}$, and for LIC in Odisha, the pattern is $5 \% \mathrm{SP}+17.5 \% \mathrm{ES}$. At all sites in both states, direct spraying occurs twice weekly. As a result, foraging bees in the field come 


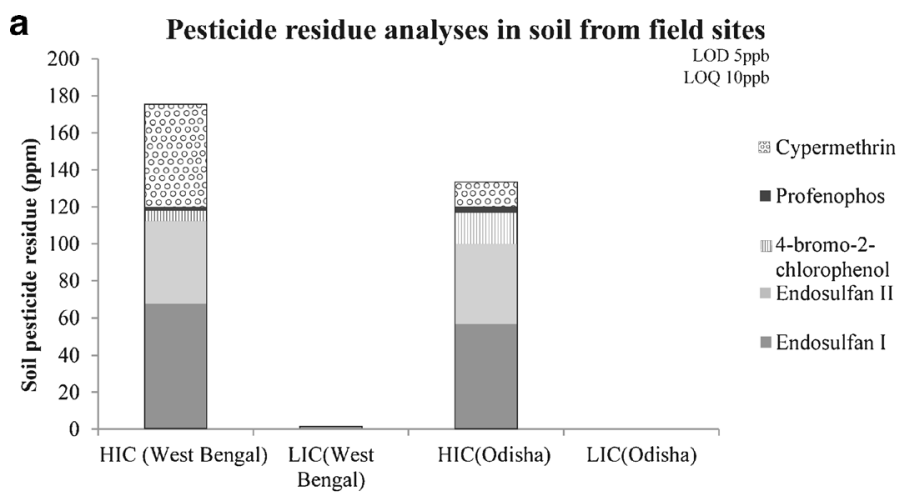

Field sites in both states

b

Mean cropping intensity $(\%)$ across sites

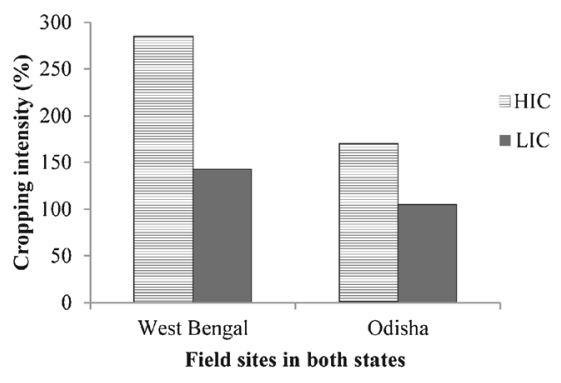

C

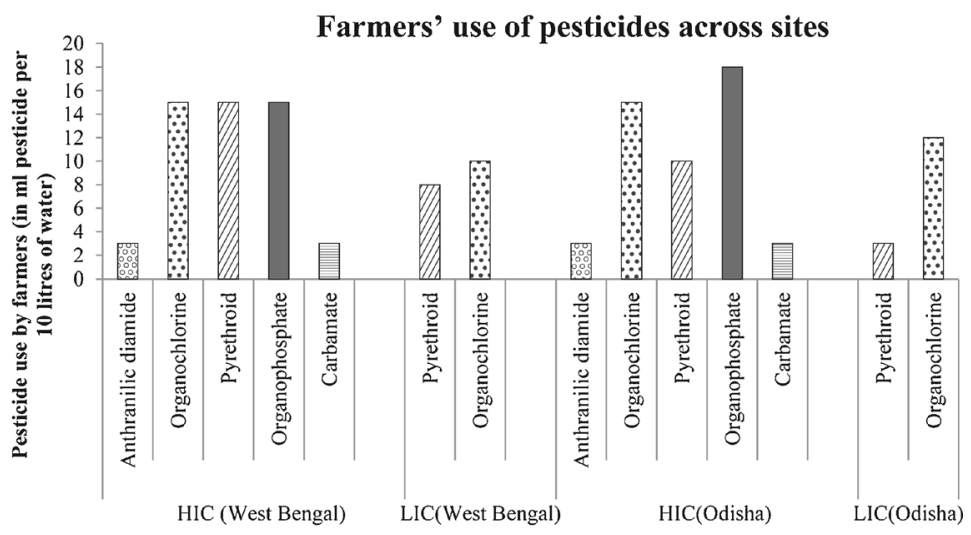

Field sites in both states

Figure 1. a Pesticide residue analyses done in soil and expressed in ppm. Facilities are provided by SGS India (Pvt.) Ltd. b Mean cropping intensities (in \%) of the field sites are shown. Data provided by a Government of India census. c Farmers' practices of pesticide use ( $\mathrm{mL}$ of pesticide used per $10 \mathrm{~L}$ of water) across all field sites are given as the mean values of the farmers' consumption of pesticides for each site. HIC stands for high cropping intensity site and LIC stands for low cropping intensity site. 
into direct contact with these pesticides. Accordingly, a comparable treatment was calculated for multiple 2$\mathrm{mL}$ feeder tubes, each containing 3 molar sugar syrup. Experimental treatments were D0 (control), D1 (5 \% OP+1.5 \% SP+5.5\% ES), D2 (12.5\% $\mathrm{OP}+4 \% \mathrm{SP}+15 \% \mathrm{ES}), \mathrm{D} 3(20 \% \mathrm{OP}+6.5 \% \mathrm{SP}+$ $23.5 \% \mathrm{ES}), \mathrm{D} 4(25 \% \mathrm{OP}+8 \% \mathrm{SP}+29 \% \mathrm{ES})$ and $\mathrm{D} 5(30 \% \mathrm{OP}+10 \% \mathrm{SP}+35 \% \mathrm{ES})$.

\subsection{Honey bee survival analyses}

Kaplan-Meier survival analyses were performed to determine the cumulative survival functions, median survival and hazard ratios of both species of treated honey bees in the laboratory with respect to various treatments for a period of up to $6 \mathrm{~h}$ (Klein and Moeschberger 2003; Visser and Blacquière 2010; Archer et al. 2014).

\subsection{Estimation of enzyme activity}

Estimations of enzyme activity in laboratory experiments were done immediately after $6 \mathrm{~h}$ of exposure of the bees to pesticides (treatments as in Methods section). They were immediately frozen in liquid nitrogen before assays were done. For estimation of enzyme activities of bee samples from the field sites, live bees were frozen in liquid nitrogen in the field immediately after collection and brought to the laboratory for further analyses.

\subsubsection{Preparation of tissue homogenate}

Homogenates of whole bees were prepared with modifications to the method described by Fujiyuki et al. 2009. Honey bee bodies were ground and homogenized in phosphate buffer ( $\mathrm{pH}$ 7.0) using a Dounce homogenizer (Sigma, USA), and a short spin was given in phosphate buffer ( $\mathrm{pH}$ 7.0) for $5 \mathrm{~min}$ at $400 \mathrm{~g}$. Centrifugation was done at $16,100 \mathrm{~g}$ at $4{ }^{\circ} \mathrm{C}$ for 20 min with $1 \%$ Triton-X to facilitate cell lysis. The supernatant was collected for assay.

\subsubsection{Determination of protein concentration}

Protein concentration was determined following the Bradford method (Bradford 1976), using bovine serum albumin as a standard.

\subsubsection{Superoxide dismutase (SOD)}

SOD enzyme activity was based on a modified protocol of Marklund and Marklund (1974). SOD activity was determined by auto-oxidation of $0.2 \mathrm{mM}$ pyrogallol solution (in $50 \mathrm{mM}$ Tris-Cacodylic acid buffer, $\mathrm{pH} 8.2$, having $1 \mathrm{mM}$ DTPA) by sample SOD using pure superoxide dismutase obtained from Sigma as a standard. Readings were taken using a Shimadzu UV$1700 \mathrm{UV}-$ VIS spectrophotometer at $420 \mathrm{~nm}$ for $1 \mathrm{~min}$ intervals up to $6 \mathrm{~min}$. SOD activity was expressed as $\mu \mathrm{g}$ of SOD per $\mathrm{mL}$ of reaction mixture per minute per gram of honey bee tissue $\left(\mu \mathrm{g} \mathrm{mL} \mathrm{min}^{-1}\right)$.

\subsubsection{Catalase (CAT)}

CAT enzyme activity was measured based on the protocol provided by Aebi (1984), with modifications. CAT activity was estimated by a decrease in the absorbance of $30 \mathrm{mM} \mathrm{H}_{2} \mathrm{O}_{2}$ at $240 \mathrm{~nm}$ at $30 \mathrm{~s}$ by spectrophotometric method (Shimadzu UV-1700 UV-VIS spectrophotometer). CAT activity was expressed as $\mathrm{mol} \mathrm{min}^{-1} \mathrm{mg}^{-1}$.

\subsection{Western blot and quantification of xanthine oxidase (XOX)}

\subsubsection{Preparation of protein samples}

Whole honey bees were ground and samples were washed in chilled 1X PBS and were homogenized in protein extraction buffer $\mathrm{pH} 7.5[50 \mathrm{mM}$ Tris- $\mathrm{HCl}$, $250 \mathrm{mM} \mathrm{NaCl}, 0.5 \% \mathrm{NP} 40,10 \%$ glycerol and $0.5 \%$ EDTA-free protease inhibitor cocktail (Roche, California, USA)] using a Dounce homogenizer (Sigma, USA) for $5 \mathrm{~min}$. The tissue lysates were then subjected to centrifugation at $14,700 \mathrm{~g}$ at $4{ }^{\circ} \mathrm{C}$ for $20 \mathrm{~min}$. The supernatants were collected from each sample and concentrations of protein were estimated by the Bradford method (Bradford 1976).

\subsubsection{Western blotting}

One hundred micrograms of total protein extract from each of the fields (A. dorsata from West Bengal and Odisha; A. cerana from Odisha), as well as from the laboratory samples (both $A$. dorsata and $A$. cerana across treatments), was fractionated by SDS- 
PAGE and transferred to PVDF+membrane (Millipore, Massachusetts, USA), followed by incubation with a rabbit polyclonal antibody to xanthine oxidase (Santa Cruz, California, USA) and HRP-conjugated secondary antibodies (Pierce, Illinois, USA). Immunoreactive bands were visualized using Immobilon ${ }^{\mathrm{TM}}$ Western chemiluminescence HRP substrate (Millipore, Massachusetts, USA). Equal loading of protein samples was confirmed by coomassie blue staining of the gel (Welinder and Ekblad 2011). The blots were scanned; bands were normalized by coomassie and quantitated using the GelDoc XR system and Quantity One ${ }^{\circledR}$ software version 4.6.3 (Bio-Rad, California, USA).

The change in expression of xanthine oxidase was studied in Apis dorsata and Apis cerana samples exposed to treatments D0, D1, D2, D3, D4 and D5. Apis dorsata samples across six treatments are referred to as $\mathrm{AD} 0, \mathrm{AD} 1$, $\mathrm{AD} 2, \mathrm{AD} 3, \mathrm{AD} 4$ and $\mathrm{AD} 5$, respectively, as shown in Figure 6a, b. Apis cerana samples across treatments are referred to as $\mathrm{AC} 0, \mathrm{AC} 1, \mathrm{AC} 2, \mathrm{AC} 3, \mathrm{AC} 4$ and $\mathrm{AC} 5$, respectively, as shown in Figure 6c, d.

\subsection{Data analyses}

Each field and treatment sample for enzyme assay included 30 individuals for A. cerana and 20 individuals for $A$. dorsata, to standardize for equivalent sample weights. All individuals were randomly sampled. For $A$. dorsata, nine replicate field samples were taken for both landscapes and for A. cerana, six replicates were taken for the Odisha landscape. For dosage experiments, there were six replicates each for all the enzyme assays for both species. For all Western blot experiments, five replicates were taken. The normality of the data was checked using the Shapiro-Wilk Test. Where data was not found to be normal, a non-parametric test was carried out. For non-normal data, a Mann Whitney $U$ test was done to compare two means and a Kruskal-Wallis test was done to compare more than two means. All statistical tests were performed using SPSS V. 16. Samples from the field were pooled across the region, i.e., HIC samples contained individuals from both West Bengal and Odisha. The same was true for LIC. Results are presented as means \pm standard errors, indicated in graphs as error bars. Kaplan-Meier survival analyses were performed using Medcalc software (V13.1.2).

\section{RESULTS}

\subsection{Agricultural intensification landscapes}

The high intensity cropping area (HIC) in each of the agricultural landscapes had a high soil pesticide residue (Figure 1a), and was cropped intensively (Figure 1b). Compared to HIC, the low cropping intensity areas (LIC) had negligible or no pesticide residues in the soil (i.e., below the detection limit) (Figure 1a) and had a lower cropping intensity (Figure 1b). It was observed that $0.38 \mathrm{ppm}$ carbofuran, $67.23 \mathrm{ppm}$ and $44.73 \mathrm{ppm}$ of endosulfan I and II, respectively, $1.91 \mathrm{ppm}$ of profenophos, $5.57 \mathrm{ppm}$ of 4-bromo-2-chlorophenol (a metabolite of profenophos) and 55.78 ppm cypermethrin were present in the soil sampled from the HIC site in West Bengal. In comparison, the LIC site in West Bengal contained only 1.4 ppm of endosulfan I in the soil pesticide residue analyses. Similarly, in Odisha, the HIC site was found to contain higher soil pesticide residues $(0.2 \mathrm{ppm}$ carbofuran, $56.55 \mathrm{ppm}$ and $43.15 \mathrm{ppm}$ of endosulfan I and II, respectively, $16.85 \mathrm{ppm}$ of 4-bromo-2-chlorophenol, $3.44 \mathrm{ppm}$ of profenophos and 12.88 ppm of cypermethrin) compared to the LIC site, where no such pesticides were detected in the soil. Rainfall, temperature and humidity conditions in the HIC and LIC areas in both landscapes were similar, and climographs for all the field sites across both states have been furnished in the supplementary material (Supplementary Figure 1). Farmers' consumption pattern of pesticides across landscapes is shown in Figure 1c. The cropping pattern in the respective landscapes was similar (Supplementary Table 1).

Land use maps of both sites in both states show a distinct difference between HIC and LIC. A higher percentage of land is used for agriculture in the HIC sites of both states compared to their respective LIC counterparts. The maps also further confirm that the LIC zones in both states have a higher percentage of forest cover or natural vegetation compared to their respective HIC counterparts (Figure 2).

\subsection{Pesticide residue in honey bees}

The pesticide residues detected in honey bees helped validate our choice of gradients. 
Honey bees, sampled from high intensity cropping sites in both states, had high residues of dimethoate and cypermethrin in them. Honey bees sampled from low intensity cropping sites had no or very little pesticide residue (Figure 3). It was observed that $A$. dorsata, sampled from West Bengal HIC, had $0.77 \mathrm{ppm}$ of cypermethrin and $0.23 \mathrm{ppm}$ of dimethoate residues, whereas $A$. dorsata bodies from the same state's LIC had no such pesticide residues. A. dorsata sampled from HIC site in Odisha reported 0.74 and $0.19 \mathrm{ppm}$ of cypermethrin and dimethoate, respectively, compared to Odisha LIC, which had 0.02 ppm cypermethrin (42 fold lower) and $0.09 \mathrm{ppm}$ of dimethoate (2.08 fold lower) in honey bee bodies (Figure 3a). For $A$. cerana in Odisha, 1.84 and 1.95 ppm of cypermethrin and dimethoate, respectively, were
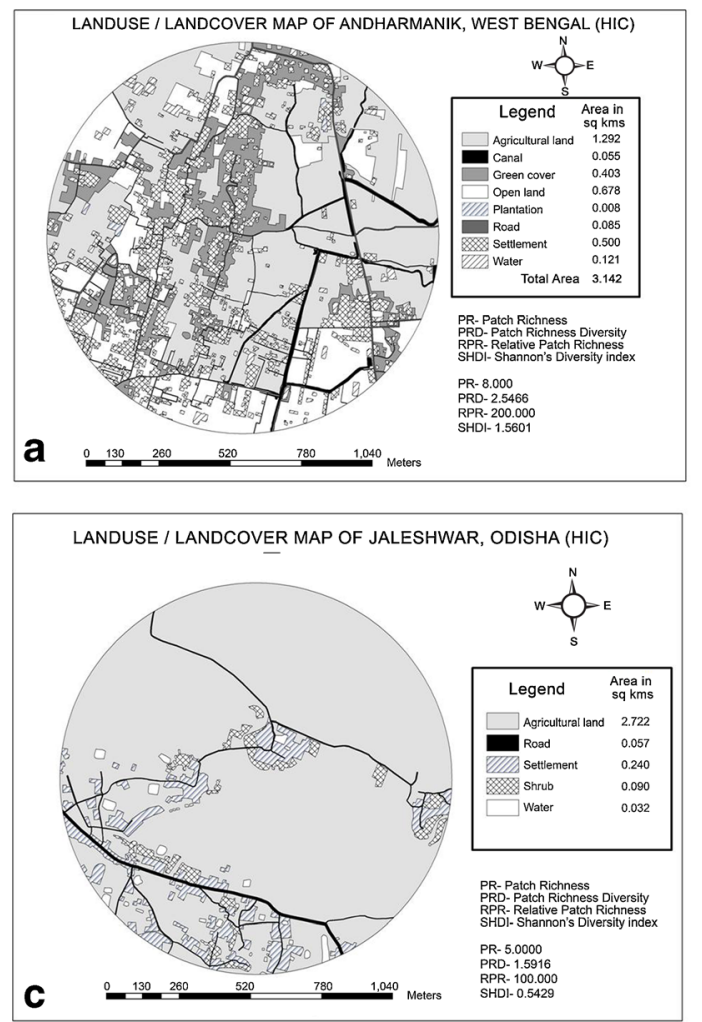

reported in the HIC compared to $0.25 \mathrm{ppm}$ of cypermethrin (7.37 fold lower) and $0.15 \mathrm{ppm}$ of dimethoate (13-fold lower) from honey bees sampled from the LIC (Figure 3b). However, a difference in pesticide residue between the two species was observed, where $A$. cerana from the Odisha LIC had 14.3-fold and 1.67-fold higher cypermethrin and dimethoate residues, respectively, compared to LIC A. dorsata. Similarly, for the Odisha HIC, A. cerana had 2.51-fold and 10.4-fold higher cypermethrin and dimethoate residues, respectively, compared to HIC A. dorsata.

\subsection{Honey bee survival analysis}

For every experiment, there was no sugar syrup remaining at the end of the $6 \mathrm{~h}$ exposure
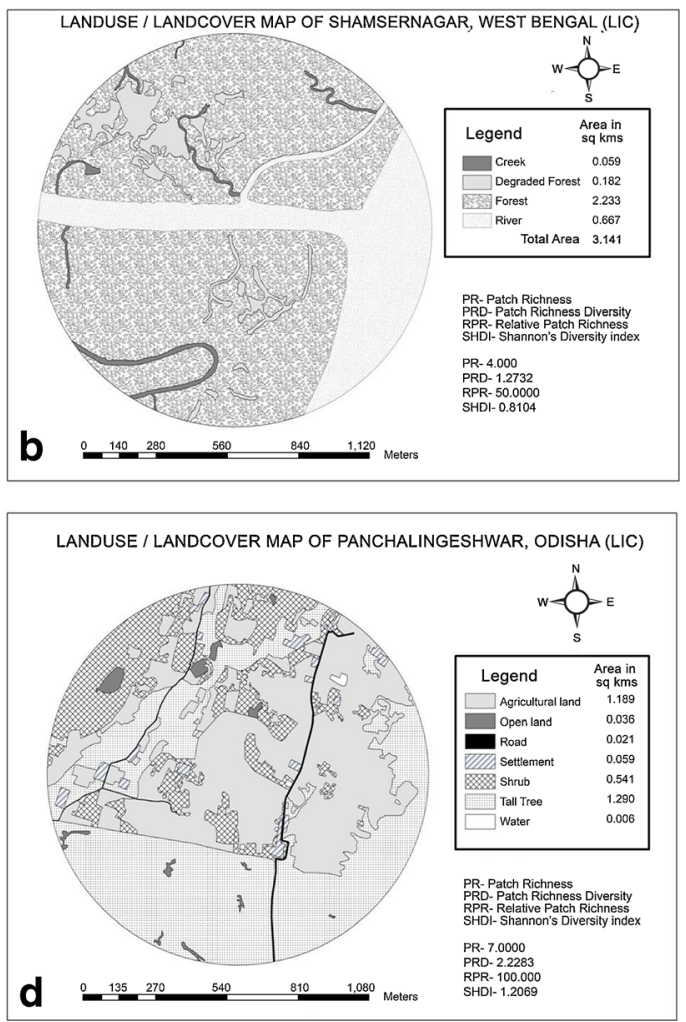

Figure 2. Landuse / landcover maps of the high intensity cropping (HIC) and low intensity cropping (LIC) sites in (a) and (b), respectively, in West Bengal and (c) and (d), respectively, in Odisha, showing amount of land used for agriculture and land covered by natural vegetation. 
a Pesticide residue analyses in honey bees from field sites

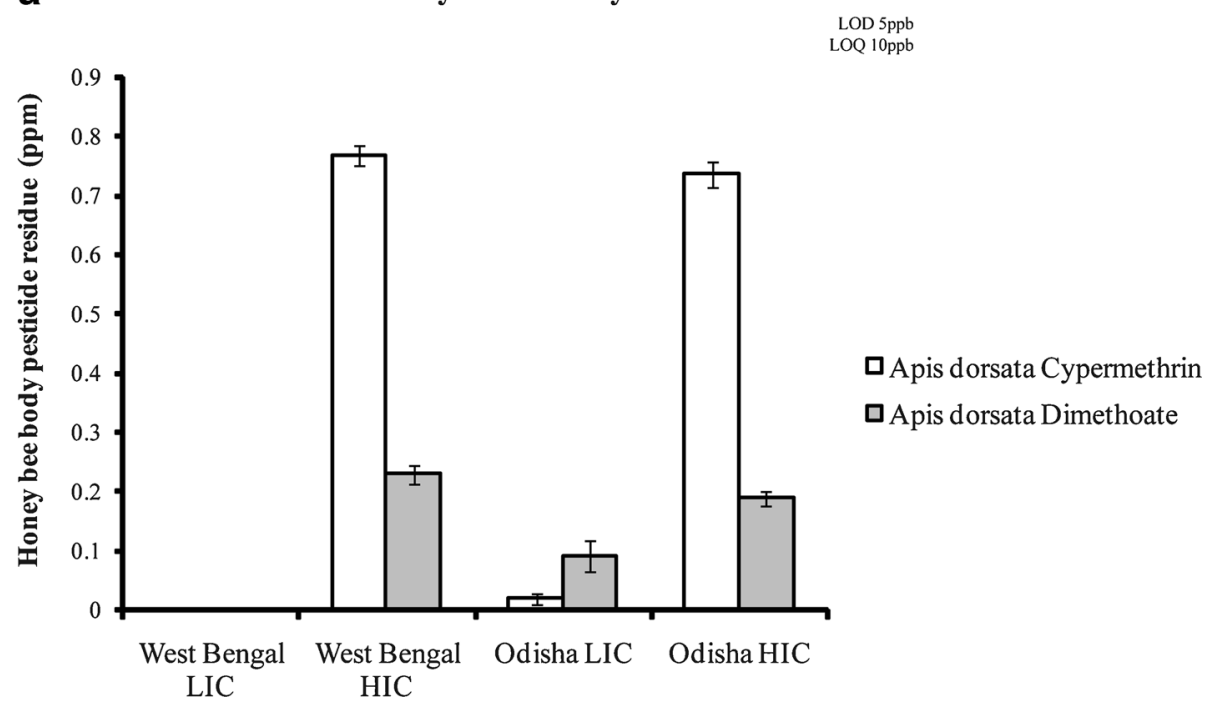

b Pesticide residue analyses in honey bees from field sites

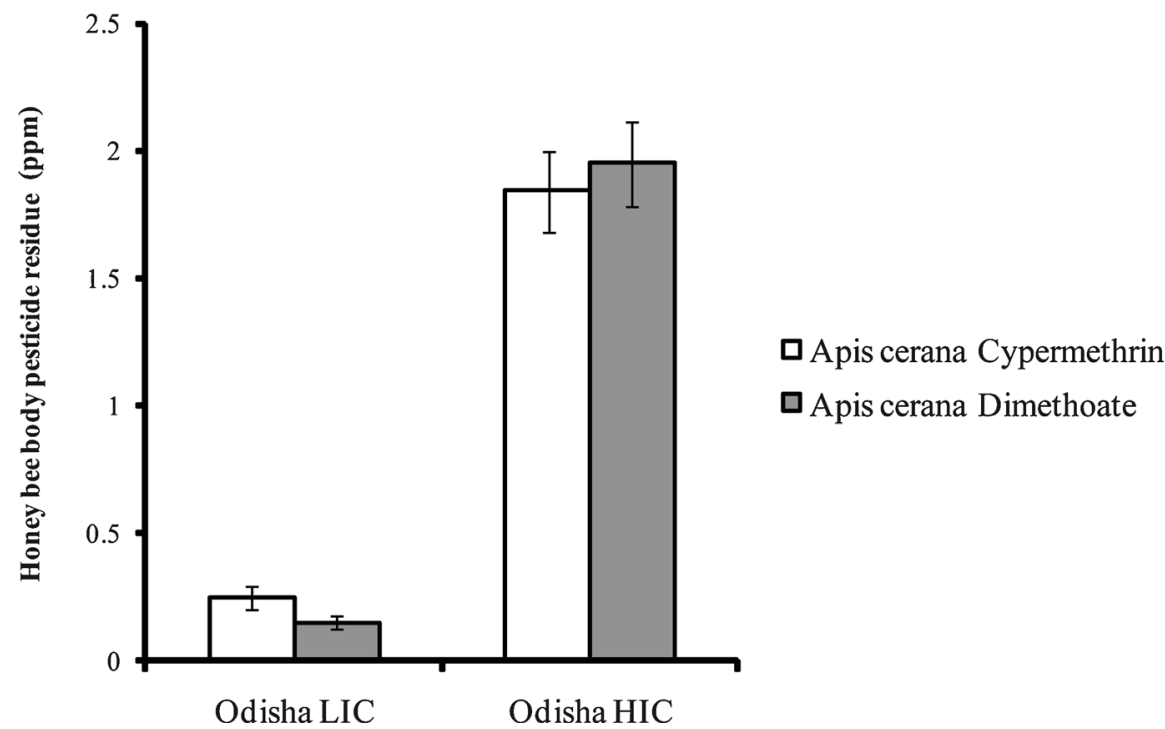

Figure 3. a Pesticide residue analyses done in Apis dorsata honey bee samples across the states of West Bengal and Odisha; b Pesticide residue analyses done in Apis cerana honey bee samples in Odisha. Facilities are provided by SGS India (Pvt.) Ltd. Pesticide residues are expressed in ppm. HIC stands for high cropping intensity site and LIC stands for low cropping intensity site.

to pesticides. A. cerana and A. dorsata individ- that the individuals of both species were uals consumed an average of 193 and $192 \mu \mathrm{L}$ of subjected to the same level of oral contamination. contaminated solution, respectively, meaning During the exposure of honey bees (both species) to 
pesticides, mortality was checked at $1 \mathrm{~h}$ intervals for each treatment. The lethal time 50 (LT50) for treatment D1 showed differences between the two studied species. But the difference narrowed at subsequent treatment and became similar from treatment D3 onward (Figure 4a). In A. dorsata, LT50 values for doses D1-D5 in order were found to be $223,33.6,11.5,6.5$ and $2.5 \mathrm{~h}$, respectively (Figure 4b). For A. cerana, it was observed that treatments D1-D3 had LT50 values higher than the experimental time of $6 \mathrm{~h}(62,22.8$ and $12.2 \mathrm{~h}$ for D1, D2 and D3, respectively). However for treatments D4 and D5, LT50 values were 3 and $2.5 \mathrm{~h}$, respectively (Figure 4a).

Kaplan-Meier survival analyses (Klein and Moeschberger 2003) were performed for both the species of honey bees exposed to different pesticide treatments. For A. cerana, survival curves for treatments were found to be significantly different from each other $\left(\chi^{2}=140.40, \mathrm{df}=5, p<0.001\right)$. The median cumulative survival at the $95 \%$ confidence interval was found to be $4 \mathrm{~h}$ for $A$. cerana.

Survival curves were also significantly different among the treatments $\left(\chi^{2}=52.67, \mathrm{df}=5, p<0.001\right)$ for A. dorsata. Median cumulative survival at the $95 \%$ confidence interval was found to be $6 \mathrm{~h}$ for $A$. dorsata.

The survival curves for different treatments are shown in Figure 4b, c for both species of honey bee. For A. dorsata, cumulative survival was higher than for A. cerana for all five treatments (D1 to D5) up until the third hour of observation (Figure 4b). For A. cerana, there was a drop in cumulative survival at the second hour of observation for treatment D5 (Figure 4c).

The survival tables and hazard ratios (Klein and Moeschberger 2003) at $95 \%$ confidence intervals for both species of honey bees are available in the supplementary material (Supplementary Tables 2 and 3).

\subsection{Laboratory experiments}

\subsubsection{Activity assay of SOD and CAT}

In the laboratory experiment, a steady rise in the SOD and CAT activity levels were observed in both A. dorsata and A. cerana (Figure 5a, b).
For A. dorsata, a significant difference among treatments in CAT activity was observed (Kruscal-Wallis test, $p=0.001$ ) and a significant difference between D0 and treatment was observed from D2 (one-tailed Mann Whitney $\mathrm{U}$ test, $p=0.001$ ) onwards (Figure 5a). Mean CAT enzyme activities were found to be 1.97 $( \pm 0.2) \mathrm{mol} \mathrm{min}^{-1} \mathrm{mg}^{-1}, 3.98( \pm 0.8) \mathrm{mol} \mathrm{min}^{-1}$ $\mathrm{mg}^{-1}, 5.24( \pm 1.2) \mathrm{mol} \mathrm{min}^{-1} \mathrm{mg}^{-1}, 6.23( \pm 1.6)$ $\mathrm{mol} \mathrm{min}{ }^{-1} \mathrm{mg}^{-1}, 8.31( \pm 0.5) \mathrm{mol} \mathrm{min}^{-1} \mathrm{mg}^{-1}$ and $12.04( \pm 2.1) \mathrm{mol} \mathrm{min}^{-1} \mathrm{mg}^{-1}$, respectively for treatments D0-D5.

A significant difference was also observed for SOD (Kruscal-Wallis test, $p=0.015$ ), and in this case a significant difference between the control and a treatment was observed at D5 (one-tailed t-test; $\mathrm{t}=-2.488, \mathrm{df}=10, p=0.016$ ) (Figure 5a). Mean SOD enzyme activities were found to be $25.53( \pm 2.24) \mu \mathrm{g} \mathrm{mL}{ }^{-1} \mathrm{~min}^{-1}$, $26.09( \pm 1.241) \mu \mathrm{g} \mathrm{mL}^{-1} \mathrm{~min}^{-1}, 29.06( \pm 0.536)$ $\mu \mathrm{g} \mathrm{mL}{ }^{-1} \min ^{-1}, 30.21( \pm 1.099) \mu \mathrm{g} \mathrm{mL}{ }^{-1} \mathrm{~min}$ ${ }^{-1}, 30.45( \pm 0.694) \mu \mathrm{g} \mathrm{mL}^{-1} \mathrm{~min}^{-1}$ and 32.86 $( \pm 1.907)$ across treatments D0-D5, respectively.

For A. cerana, a significant increase in levels of SOD (Kruscal-Wallis test, $\mathrm{p}=0.003$ ) was observed. A significant difference with respect to D0 was observed from D2 onwards (onetailed Mann Whitney U test, $p=0.026$ ). Mean SOD enzyme activities in $A$. cerana for treatments D0-D5 were found to be $10.45( \pm 0.08)$ $\mu \mathrm{g} \mathrm{mL}^{-1} \mathrm{~min}^{-1}, 12.04( \pm 0.4) \mu \mathrm{g} \mathrm{mL}^{-1} \min ^{-1}$, $16.17( \pm 0.78) \mu \mathrm{g} \mathrm{mL}^{-1} \mathrm{~min}^{-1}, 17.11( \pm 2.1) \mu \mathrm{g}$ $\mathrm{mL}^{-1} \min ^{-1}, 17.65( \pm 0.8) \mu \mathrm{g} \mathrm{mL}^{-1} \mathrm{~min}^{-1}$ and $18.53( \pm 2) \mu \mathrm{g} \mathrm{mL}^{-1} \mathrm{~min}^{-1}$, respectively (Figure $5 b$ ).

A significant increase in levels of CAT activity was also found in $A$. cerana (KruscalWallis test, $P=0.00,01)$ and a significant difference between the control and a treatment was only observed from D3 onwards (one-tailed Mann Whitney $\mathrm{U}$ test, $p=0.004$ ) (Figure $5 b$ ). Mean CAT enzyme activities for A. cerana were found to be $2.03( \pm 0.12) \mathrm{mol} \mathrm{min}^{-1} \mathrm{mg}^{-1}, 2.05$ $( \pm 0.8) \mathrm{mol} \mathrm{min}^{-1} \mathrm{mg}^{-1}, 2.688( \pm 0.5) \mathrm{mol} \mathrm{min}$ ${ }^{-1} \mathrm{mg}{ }^{-1}, 5.79( \pm 0.8) \mathrm{mol} \mathrm{min}^{-1} \mathrm{mg}^{-1}, 7.88$ $( \pm 1.2) \mathrm{mol} \mathrm{min}^{-1} \mathrm{mg}^{-1}$ and $14.38( \pm 1.4) \mathrm{mol}$ $\min ^{-1} \mathrm{mg}^{-1}$ for treatments D0, D1, D2, D3, D4 and $\mathrm{D} 5$ respectively. 

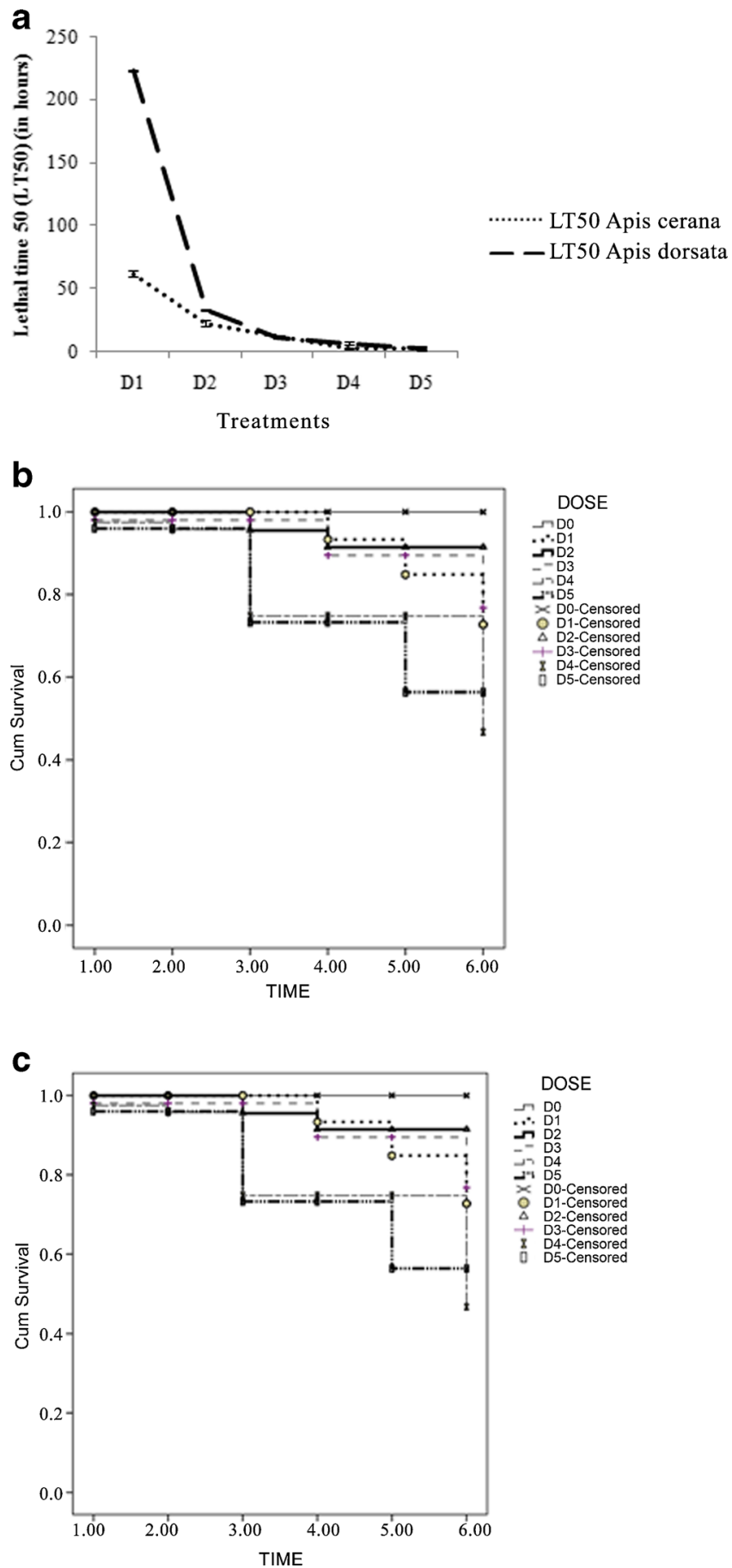

Figure 4. a Lethal time 50 (LT50) of both species of honey bees across treatments D1-D5; b Cumulative survival function for A. dorsata for treatments D0-D5 up to $6 \mathrm{~h}$; c Cumulative survival function for $A$. cerana for treatments D0-D5 up to $6 \mathrm{~h}$. Treatments are D0 (control), D1 (5\% OP+1.5\% SP+5.5\% ES), D2 (12.5\% OP+4 \% SP+15\% ES), D3 (20 \% OP+6.5\% SP+23.5\% ES), D4 (25\% OP+8 \% SP+29\% ES) and D5 (30\% OP+10\% SP+35\% ES), where OP: organophosphorus pesticide; SP: synthetic pyrethroid; ES: endosulfan pesticide. 


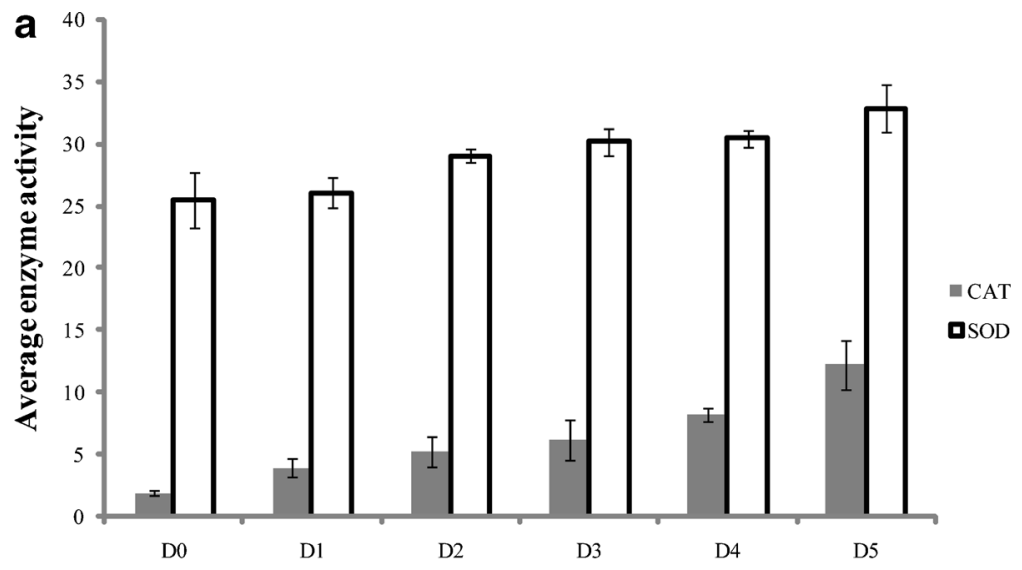

A. dorsata samples across treatments

CAT enzyme activity in $\mathrm{mol} \mathrm{min}^{-1} \mathrm{mg}^{-1} \quad$ SOD enzyme activity in $\mu \mathrm{g} \mathrm{ml}^{-1} \mathrm{~min}^{-1}$

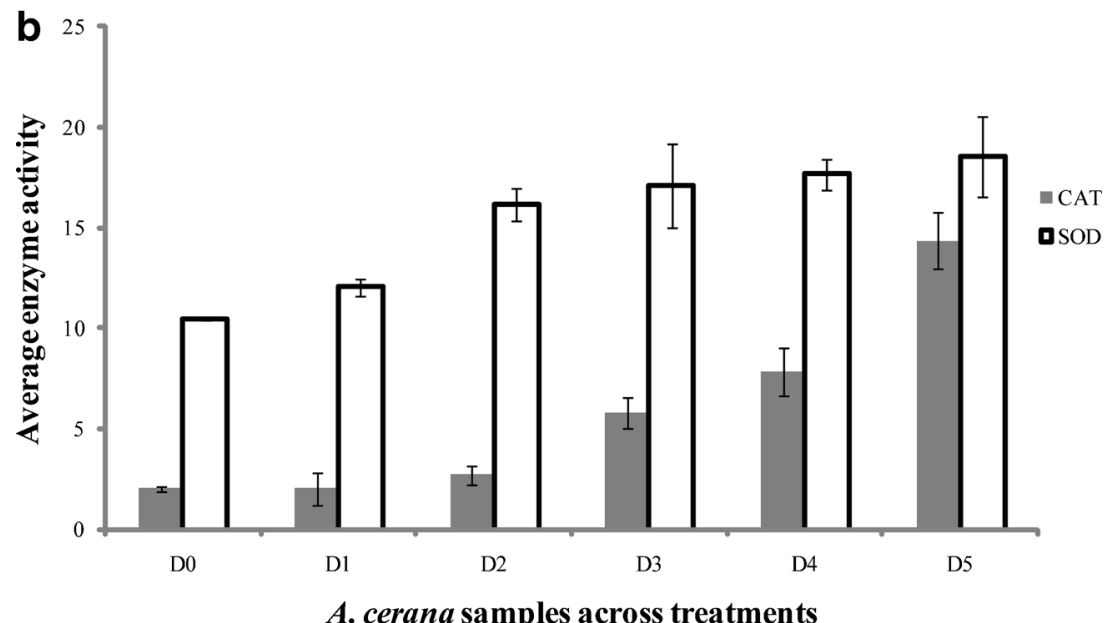

CAT enzyme activity in mol $\mathrm{min}^{-1} \mathrm{mg}^{-1} \quad$ SOD enzyme activity in $\mu \mathrm{g} \mathrm{ml}^{-1} \mathrm{~min}^{-1}$

Figure 5. Activities of antioxidant enzymes superoxide dismutase (SOD) and catalase (CAT) in the treated honey bees (a). A . dorsata individuals across treatments D0-D5; b A. cerana individuals across treatments D0$\mathrm{D} 5$; $\mathrm{SOD}=$ Superoxide dismutase, CAT $=$ Catalase. ${ }^{*} \mathrm{p}<0.05,{ }^{*} \mathrm{p}<0.01 . \mathrm{D} 0=$ control; $\mathrm{D} 1=5 \% \mathrm{OP}+1.5 \% \mathrm{SP}+$ $5.5 \% \mathrm{ES} ; \mathrm{D} 2=12.5 \% \mathrm{OP}+4 \% \mathrm{SP}+15 \% \mathrm{ES} ; \mathrm{D} 3=20 \% \mathrm{OP}+6.5 \% \mathrm{SP}+23.5 \% \mathrm{ES} ; \mathrm{D} 4=25 \% \mathrm{OP}+8 \% \mathrm{SP}+$ $29 \% \mathrm{ES}$; and $\mathrm{D} 5=30 \% \mathrm{OP}+10 \% \mathrm{SP}+35 \% \mathrm{ES}$, where OP: organophosphorus pesticide; SP: synthetic pyrethroid; ES: endosulfan pesticide.

\subsubsection{Gene expression assay of $\mathrm{XOX}$ (by studying change in protein expression by western blot analyses)}

A similar response pattern was observed in the experimental honey bee samples treated with pesticide laden sugar syrup at varying concentrations. There was a significant differ- ence in XOX protein expression among six treated samples-D1, D2, D3, D4 and D5. There was a significant increase in XOX protein expression from D3 onwards in all experimental samples when compared with D0 (one-tailed Mann Whitney U test, $\mathrm{p}=0.001$ ) for $A$. dorsata. XOX protein was upregulated 0.45 -fold $( \pm 0.05)$ for D1, 0.73-fold $( \pm 0.09)$ for D2, 2.51-fold 
$( \pm 0.02)$ for D3, 4.48-fold $( \pm 0.03)$ for D4 and 6.45 -fold $( \pm 0.10)$ for $\mathrm{D} 5$, respectively, when compared with D0 in A. dorsata (Figure 6a, b).

A significant increase in $\mathrm{XOX}$ protein expression was also observed in A. cerana when treated bees were compared with control from D3 onwards (one-tailed Mann Whitney $\mathrm{U}$ test, $p=0.001)$. XOX protein was upregulated 1.33-fold $( \pm 0.08)$ for D1, 1.60fold $( \pm 0.12)$ for $D 2,5.14$-fold $( \pm 0.18)$ for D3, 5.98-fold $( \pm 0.2)$ for D4 and 9.31-fold $( \pm 0.08)$ for $\mathrm{D} 5$, respectively, when compared with D0 in A. cerana (Figure 6c, d).

\subsection{Field population studies}

\subsubsection{Anti-oxidant enzymes}

For Apis dorsata, there was no significant difference in mean values of SOD (Mann Whitney $\mathrm{U}$ test, $p=0.356$ ) and CAT (Mann Whitney U test, $p=0.433$ ) between the HICs of both landscapes. The same was true for the LIC SOD (Mann Whitney U test, $p=0.191$ ) and CAT (Mann Whitney U test, $P=0.456$ ). Since there were no significant differences in SOD and CAT for A. dorsata, values between respective HIC and LICs were pooled across landscapes for further analyses. A significant increase (one-tailed t-test; $\mathrm{t}=-3.094, \mathrm{df}=16$, $p=0.0034$ ) was observed in levels of SOD activity of $A$. dorsata samples collected from the HIC. The mean SOD level in HIC samples was $13.39 \mu \mathrm{g} \mathrm{mL} \mathrm{gm}^{-1}( \pm 0.863)$ and that in LIC samples was $9.71 \mu \mathrm{g} \mathrm{mL}^{-1} \min ^{-1}( \pm 1.016)$ (Figure 7a). A significant increase (one-tailed ttest; ; $\mathrm{t}=-41.547, \mathrm{df}=16, p=0.0001$ ) was also observed in levels of CAT activity in A. dorsata samples in the HIC $\left(3.56 \mathrm{~mol} \mathrm{~min}^{-1} \mathrm{mg}^{-1} ; \pm 0.57\right.$ ) compared to LIC (9.24 $\left.\mathrm{mol} \mathrm{min}^{-1} \mathrm{mg}^{-1} ; \pm 2.19\right)$ (Figure 7 a).

A significant increase in levels of SOD (onetailed t-test; $\mathrm{t}=-10.092, \mathrm{df}=10, p=0.0001$ ) and CAT activities (one-tailed t-test, $\mathrm{t}=-5.18811, \mathrm{df}=$ $10, p=0.0001$ ) was also observed in A. cerana collected from the HIC when compared with the LIC (Figure 7b). Mean SOD activity in the HIC was $13.5 \mu \mathrm{g} \mathrm{mL} \min ^{-1}( \pm 0.524)$ and
$6.3 \mu \mathrm{g} \mathrm{mL} \mathrm{min}^{-1}( \pm 0.489)$ in the LIC. Mean value for CAT activity in the HIC was $1.599 \mathrm{~mol} \mathrm{~min}^{-1} \mathrm{mg}^{-1}( \pm 0.59)$ and $6.77 \mathrm{~mol} \mathrm{~min}$ ${ }^{-1} \mathrm{mg}^{-1}( \pm 0.47)$ in the LIC (Figure $\left.7 \mathrm{~b}\right)$.

\subsubsection{Gene expression assay of XOX (by studying change in protein expression by western blot analyses)}

Western blot analyses revealed a significant difference in the expression of XOX in all field samples across both landscapes (one-tailed Mann Whitney U test; $n=5)$. For Apis dorsata, there was an increase of 2.02-fold $( \pm 0.07)$ (onetailed Mann Whitney U test; $\mathrm{n}=5 ; p=0.008$ ) in $\mathrm{XOX}$ expression in HIC samples from West Bengal when compared with LIC samples from the same. In Odisha samples, XOX was upregulated by 1.99 -fold $( \pm 0.14)$ (one-tailed Mann Whitney U test; $\mathrm{n}=5 ; p=0.008$ ) in HIC, compared to $A$. dorsata populations from the LIC (Figure 8a, b). In another set of experiments, change in XOX expression level was observed for Apis dorsata and Apis cerana samples from the Odisha landscape. In this instance too, A. dorsata populations in the HIC showed a 4.38-fold $( \pm 0.64)$ increase (one-tailed Mann Whitney U test; $n=5 ; p=0.009$ ) in XOX protein expression when compared with LIC populations. A. cerana samples in the HIC also showed a significant rise (one-tailed Mann Whitney $\mathrm{U}$ test; $\mathrm{n}=5 ; p=0.009$ ) in XOX protein expression (1.52 fold \pm 0.05$)$ when compared to the populations from the LIC (Figure 8c, d).

\section{DISCUSSION}

A large number of developing countries around the world have intensified their agriculture in recent decades, and consequently there has been a significant rise in pesticide use in these countries (Schreinemachers and Tipraqsa 2012). An assessment of native honey bee response to elevated pesticide exposures in these countries could be critical to determine non-target pesticide impacts, and it is in this context that the results of this study are presented. For any comprehensive risk assessment of pesticides on non-target organisms, it 

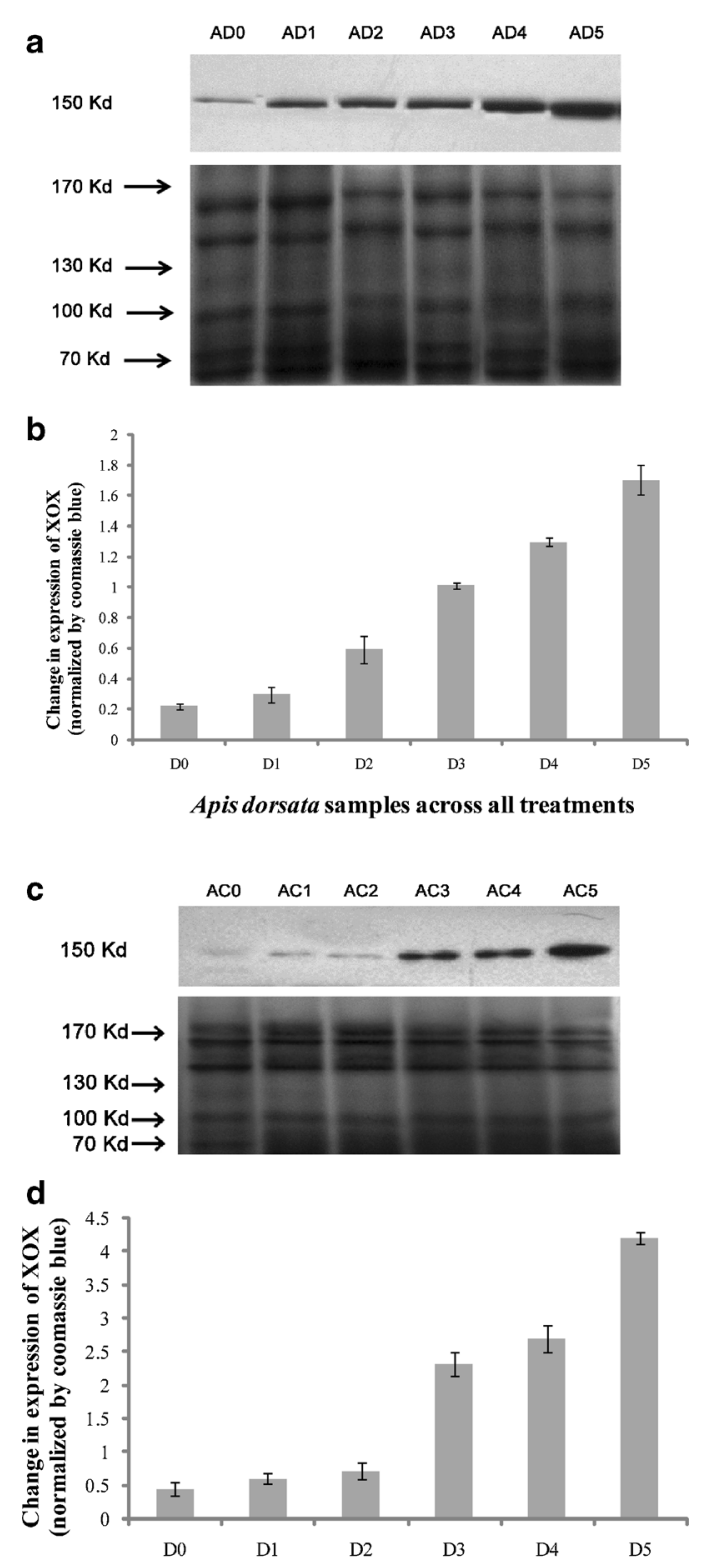

Apis cerana samples across all treatments

Figure 6. (a) Representative blots for xanthine oxidase (XOX) and respective SDS-PAGE gels stained with Coomassie blue for Apis dorsataindividuals across treatments D0 (control), D1 (5\% OP+1.5\% SP+5.5\% ES), D2 $(12.5 \% \mathrm{OP}+4 \% \mathrm{SP}+15 \% \mathrm{ES}), \mathrm{D} 3(20 \% \mathrm{OP}+6.5 \% \mathrm{SP}+23.5 \% \mathrm{ES}), \mathrm{D} 4(25 \% \mathrm{OP}+8 \% \mathrm{SP}+29 \% \mathrm{ES})$ and $\mathrm{D} 5$ (30 \% OP+10\% SP+35\% ES), where OP: organophosphorus pesticide; SP: synthetic pyrethroid; ES: endosulfan pesticide. (b) Graph indicates the change in expression of XOX normalized by Coomassie blue. (c) Representative blots for xanthine oxidase (XOX) and respective SDS-PAGE gels stained with Coomassie blue for A. cerana individuals across treatments D0-D5. (d) Graph indicates the change in expression of XOX normalized by Coomassie blue. ${ }^{* *} p<0.05 . \mathrm{AD} 0, \mathrm{AD} 1, \mathrm{AD} 2, \mathrm{AD} 3, \mathrm{AD} 4$ and $\mathrm{AD} 5$ are treated $A$. dorsata individuals with respect to treatments $\mathrm{D} 0, \mathrm{D} 1, \mathrm{D} 2, \mathrm{D} 3, \mathrm{D} 4$ and $\mathrm{D} 5$, respectively; $\mathrm{AC} 0, \mathrm{AC} 1, \mathrm{AC} 2, \mathrm{AC} 3, \mathrm{AC} 4$ and $\mathrm{AC} 5$ are treated A. cerana individuals with respect to $\mathrm{C} 0, \mathrm{C} 1, \mathrm{C} 2, \mathrm{C} 3, \mathrm{C} 4$ and $\mathrm{C} 5$, respectively. 
would be essential to assess toxic responses in laboratory, semi-field as well as field experiments (Osborne 2012). But very few studies have addressed toxic responses at all levels with regards to native bees (Osborne 2012). For India, there is only one example of this kind, where the response of $A$. cerana to pesticide application in a cardamom plantation in India (Stanley et al. 2010) was investigated through field experiment.

Our result clearly indicated a distinct pesticide use gradient in the studied agricultural landscapes, both in terms of pesticide residues in soil as well as in the honey bee bodies. However, with respect to the pesticide residue in the honey bee samples, A. cerana had between 1.67-fold and 14.3-fold higher pesticide residue levels - both in the LIC as well as in the HIC-compared to A. dorsata. We reckon that this difference between the two species in terms of pesticide residues in their bodies is perhaps due to the differential levels of pesticide exposures of the two species. The differences in pesticide exposure is perhaps due to the fact that $A$. cerana nests (or managed hives) are essentially in close proximity to the crop fields in our study sites, and are generally closer to ground level, in contrast with the $A$. dorsata nests, which are generally much higher up in tall tree crowns (Starr et al. 1987; Koetz 2013). Also, A. cerana, having a much shorter foraging range of 1 to $1.5 \mathrm{~km}$ (Dhaliwai and Sharma 1974; Dyer and Seeley 1991; Abrol 2011; Partap 2011; Koetz 2013), may be more dependent on crop flowers compared to $A$. dorsata, which due to its larger foraging range of more than $5 \mathrm{~km}$ (Koeniger and Vorwohl 1979; Abrol 2011) and larger size, can have greater access to non-crop natural and seminatural vegetations that are free from pesticides. These reasons can possibly be responsible for the observed differences in pesticide loads in the bodies of the two honey bee species. However, the reason for this difference in pesticide retention, between the two species, would require further investigation.

Through the survival analyses of the studied species, we assessed the hazards posed by pesticides to the honey bees in terms of cumulative survival of treatments having comparable concentrations of pesticides applied in the field. As is apparent from the obtained LT50 values in A. cerana, for treatment as low as D1, LT50 is $62 \mathrm{~h}$, whereas for D3 it is only $12.2 \mathrm{~h}$. In $A$. dorsata, the LT50 value for D3 was found to be $11.5 \mathrm{~h}$. In reality, honey bees are exposed for longer durations in the field-hence in actuality, the LT50 values can be even lower for the field honey bees. This suggests that there could be significant mortality in natural populations at the field application treatments.

The overall LT50 data reflects that $A$. dorsata had better survivability compared to $A$. cerana, as is evident from the higher median value of survival time at the $95 \%$ confidence interval. This is also evident from cumulative survival plots. For treatment D4, there is a drop in cumulative survival function for $A$. dorsata at $4 \mathrm{~h}$ compared to $A$. cerana, which shows a decline at the third hour. Similarly for D5, $A$. dorsata showed a drop at the third hour compared to $A$. cerana, which shows a drop in cumulative survival function as early as in the second hour.

Our data demonstrated upregulation of antioxidant enzymes in laboratory bees exposed to graded treatments of pesticide cocktails with respect to both $A$. cerana and $A$. dorsata, and supports our first hypothesis that the oxidative stress markers will be differentially upregulated across laboratory pesticide treatments. However, these observed changes in the laboratory were with respect to the pesticides mixtures similar to pesticide combinations used in field conditions. These changes were not observed with respect to the individual pesticides. It must be mentioned that assays with respect to the individual pesticides would be required to assess the relative roles of different pesticides in triggering the enzymatic responses.

Our second hypothesis that stress markers will be differentially upregulated across pesticide use intensity in agricultural landscapes similar to laboratory responses was also confirmed by our results. The responses with respect to the stress markers in the field samples 


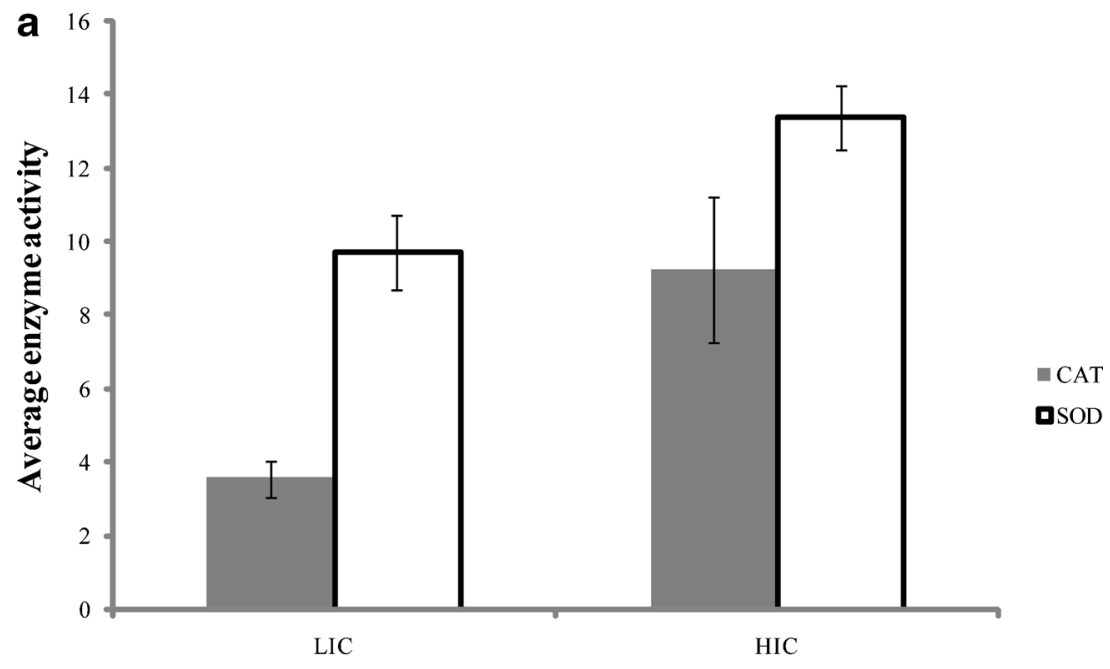

Apis dorsata samples across gradients

CAT enzyme activity in $\mathrm{mol} \mathrm{min}^{-1} \mathrm{mg}^{-1}$ SOD enzyme activity in $\mu \mathrm{g} \mathrm{m}^{-1} \mathrm{~min}^{-1}$

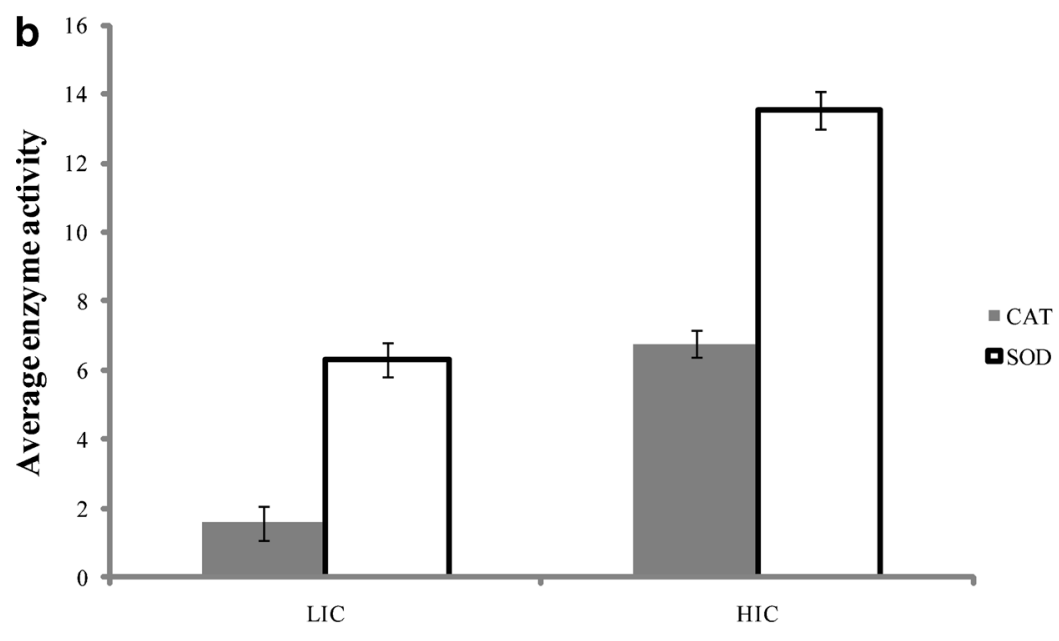

Apis cerana sample in Odisha

CAT enzyme activity in $\mathrm{mol} \mathrm{min}^{-1} \mathrm{mg}^{-1} \quad$ SOD enzyme activity in $\mu \mathrm{g} \mathrm{ml}^{-1} \mathrm{~min}^{-1}$

Figure 7. Activities of antioxidant enzymes superoxide dismutase (SOD) and catalase (CAT) in the treated honey bees a wild $A$. dorsata individuals across two agricultural intensification landscapes; b wild $A$. cerana individuals across two agricultural intensification landscapes. HIC $=$ High intensity cropping area; LIC $=$ Low intensity cropping area. $\mathrm{SOD}=$ Superoxide dismutase, $\mathrm{CAT}=$ Catalase. ${ }^{*} p<0.05,{ }^{* *} p<0.01$.

of bees collected from different areas of varying pesticide use were similar to those observed in laboratory samples. When compared with low intensity cropping areas with low or pesticide- free agronomic practices, samples collected from areas with high pesticide use showed elevated levels of SOD and CAT, the two major anti-oxidant enzymes. These results strongly 
suggest a rise in oxidative stress in honey bees associated with pesticides. Similarity in response patterns observed in treated individuals and field populations support this assertion. Our analyses of samples from two geographically separated field locations confirm that the pesticide exposure responses observed were indeed independent of geographic locations.

SOD, a potent antioxidant enzyme, scavenges for oxygen free radicals such as superoxide anion $\left(\mathrm{O}^{2-}\right)$ and eventually converts it into hydrogen peroxide $\left(\mathrm{H}_{2} \mathrm{O}_{2}\right)$. The $\mathrm{H}_{2} \mathrm{O}_{2}$ molecule is the substrate for CAT, which subsequently acts upon it, releasing oxygen $\left(\mathrm{O}_{2}\right)$ and water $\left(\mathrm{H}_{2} \mathrm{O}\right)$. Hence, their synergistic action is important in helping individuals to combat oxidative stress. CAT activity is a biomarker of exposure to an oxidative stress (Khessiba et al. 2005). CAT has been identified as a key player in dealing with ROS (Mamidala et al. 2011), and elevated levels of CAT have previously been shown in A.mellifera following laboratory exposure to xenobiotic compounds (BadiouBénéteau et al. 2012).

For $A$. cerana, treated bees showed a significant rise in SOD activity against control at D2, as well as a significant rise in CAT activity from D3 onwards. These data suggest that a significant rise in CAT activity at a higher treatment was due to the higher substrate accumulation that was being provided by SOD.

In $A$. dorsata populations, a significant rise with regards to SOD only at D5 from D0 in the dosage experiment, suggests that the $A$. dorsata population is perhaps more capable of withstanding oxidative stress compared to A. cerana. Laboratory assessment of comparative treatment responses in A. cerana and $A$. dorsata with respect to individual pesticides would reveal if our observed responses to pesticide mixtures were due to any synergistic effect. However, it must be mentioned that due to the small, fragmented mosaic of diverse crop fields in agricultural landscape in the study regions, bees are exposed to a wide variety of pesticides. Therefore, studying their individual effects in the field would not be possible.
Unlike $A$. cerana, SOD activity in $A$. dorsata was unchanged at lower treatments, and was only differentiated from D0 at D5. It is possible that the larger body size for $A$. dorsata was responsible for this observation. It may also be attributed to the fact that the $A$. cerana samples (collected from the LIC in Odisha) had a higher base level of pesticide residue in their bodies compared to A. dorsata. This could explain why we found a differential mortality between the species of honey bees in laboratory experiments. However, it must be mentioned that despite the differential base level of pesticide residues in both species of honey bees, there was a broadly similar pattern of response in the two honey bee species for treatments D1 to D5 compared to their respective D0.

In A. dorsata, it was observed that CAT activity had significantly increased from D2 onwards, whereas SOD activity had only significantly increased at treatment D5 compared to control (D0). This could be because ROS comprises a number of elements and not just superoxide anion (Bouayed and Bohn 2010). However, all ROS elements are eventually converted to $\mathrm{H}_{2} \mathrm{O}_{2}$, where CAT is predominant for removing $\mathrm{H}_{2} \mathrm{O}_{2}$ at the terminal end (Mueller et al. 1997; Barbeta et al. 2004). Hence, SOD could be only significantly upregulated when there is enough superoxide anion to work upon, whereas CAT plays a vital role in breaking down $\mathrm{H}_{2} \mathrm{O}_{2}$ produced from all ROS elements.

The xanthine oxidase catalyses conversion of hypoxanthine to xanthine and also mediates its subsequent conversion to uric acid (Aranda et al. 2007). Superoxide anion $\left(\mathrm{O}^{2-}\right)$ is an important byproduct of this reaction (Aranda et al. 2007). Elevated levels of XOX would therefore imply an increased production of $\mathrm{O}^{2-}$ and a subsequent increase in production of SOD as a preventive measure. These findings led us to hypothesize that induced SOD level during stress produces abundant hydrogen peroxide and results in induced CAT activity. Thus, upregulation in the expression of XOX levels could be correlated to an elevated enzyme activity level of both SOD and CAT, and this 
a
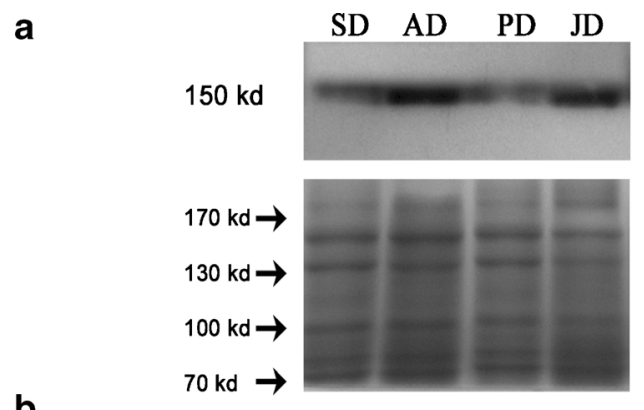

b

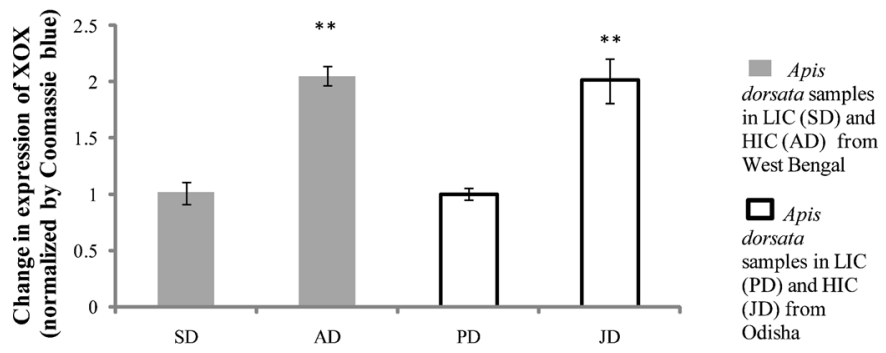

Apis dorsata samples from both field sites in two landscapes

c
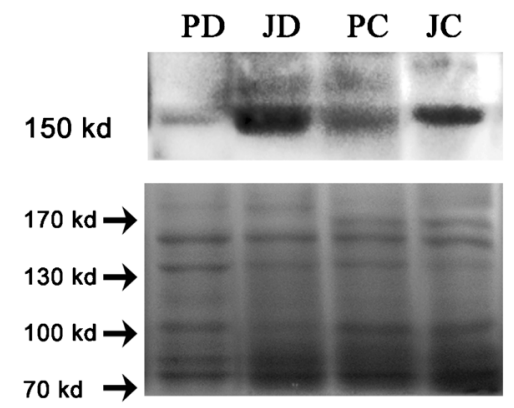

d

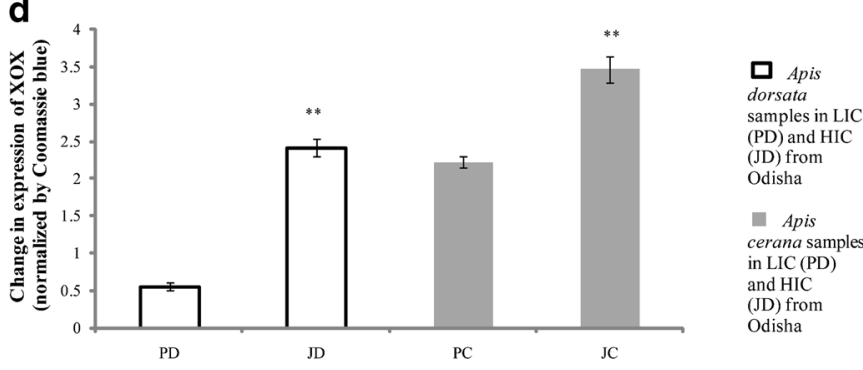

Apis dorsata and Apis cerana samples from Odisha landscape

Figure 8. (a) Representative blots for xanthine oxidase (XOX) and respective SDS-PAGE gels stained with Coomassie blue for $A$. dorsata individuals across all field sites in both landscapes of West Bengal and Odisha. (b) Graph indicates the change in expression of XOX normalized by Coomassie blue. (c) Representative blots for xanthine oxidase (XOX) and respective SDS-PAGE gels stained with Coomassie blue for A. dorsata and A. cerana individuals across field sites in Odisha. (d) Graph indicates the change in expression of XOX normalized by Coomassie blue. ${ }^{*} p<0.05$. $\mathrm{SD}, \mathrm{AD}=A$. dorsata individuals in LIC (low intensity cropping area) and HIC (high intensity cropping area), respectively, in West Bengal; $\mathrm{PD}, \mathrm{JD}=A$. dorsata individuals in LIC and HIC, respectively, in Odisha; PC, JC=A. cerana individuals in LIC and HIC, respectively, in Odisha. 
would make XOX a potent marker for pesticide-induced oxidative stress.

In our chosen study sites, as was mentioned before, spraying occurred twice weekly. Direct spraying was done even when the flowers were in bloom. Hence, field populations were exposed to pesticides directly as well as through contaminated nectar. Long-term exposure to toxic agents can occur in honey bees by transfer of pesticides sprayed on crops into the hive (Villa et al. 2000). Short duration of laboratory studies is hence only a partial measure of the lethal effect as would be applied in the field (Desneux et al. 2007).

Changes in the expression of $\mathrm{XOX}$ in honey bee species due to pesticide exposure have been shown for the first time in this study. XOX was shown to be significantly upregulated in both species across treated bees. A similar response pattern in wild bees from two kinds of landscapes with different levels of pesticide exposure, evident by different quantities of pesticide residues found in their body, clearly suggests that the expressional change of XOX observed in the field is attributable to pesticides. Our results show an increased expression level of $\mathrm{XOX}$ protein in areas of high pesticide use as well as across a pesticide treatment gradient in the lab, and this pattern is repeated also for SOD and CAT.

Physiological effects of pesticides include effects on the population, because pesticides have been reported to induce deformations of ovaries and testes in insects (George and Ambrose 2004; Medina et al. 2004). Especially in haplodiploid species, like honey bees, in which the female chooses the fertilization of ova while laying eggs, effects on the fertilization of ova, as well as differential survival of sexes in juveniles exposed to pesticide (Idris and Grafius 1993), can cause a serious threat to population survival.

In the above context, a resultant population imbalance could affect honey bee colony survival, population structure and perhaps the inter-specific behaviour of affected species. In reality, the field scenario is complex, with multi-species interactions and multiple pesticide usage.

Because sub-lethal effects of pesticides interact with numerous life-history traits involved in reproduction, they are also likely to have an impact on insect communities (Desneux et al. 2007). However, further investigation in a large trial is necessary to discern the impacts of such stress on their population dynamics.

From behavioural alteration (Whitehorn et al. 2012) to neuro-physiological changes (Palmer et al. 2013) in adults as well as in broods (Henry et al. 2012), a number of recent studies have established deleterious responses of honey bees to pesticide toxicity. As has previously been reported, A. mellifera is deficient in its genome for expression of detoxifying enzymes (Claudianos et al. 2006), and given this apparent deficient detoxification system, other detoxification systems in honey bees become important. Hence, the present study in two natural Apis bees is important, and we propose that the altered levels of the XOX-SOD-CAT combination could be used as potential response biomarkers for nontarget insects in agro-ecosystems.

However, it will also be important to assess demographic, behavioural or anatomical response markers across a field pesticide-use gradient in order to fully interpret the lessons learned from earlier experimental eco-toxicological studies. The implications for honey bees may in turn have implications for other beneficial pollinator species assemblages. This study could contribute to developing pesticide regulatory frameworks and comprehensive risk assessment, complementing laboratory experiments with suitably designed field experiments.

\section{ACKNOWLEDGMENTS}

The study was supported by an INSPIRE fellowship from the Department of Science \& Technology, Govt. of India to Priyadarshini Chakrabarti; the Department for Environment, Food and Rural Affairs (DEFRA) Darwin Initiative grant (1662) to Parthiba Basu and Barbara Smith, and a research grant to Sagartirtha Sarkar from the Department of Science \& Technology, Govt. of India. Soumik Chatterjee, Debaditya Kumar, Ritam Bhattacharya and Arnob Chatterjee helped in obtaining bee samples. Dr. Kaberi Samanta helped with the GIS maps. The Department of Agriculture, Governments of Odisha and West Bengal helped by providing the cropping intensity data. SGS India Private Limited analysed pesticide residues in soil and honey bee bodies. 


\section{APPENDIX}

List of abbreviations used in methodology section:

\begin{tabular}{|c|c|c|c|}
\hline Abbreviation & Full terminology & Abbreviation & Full terminology \\
\hline $\mathrm{HIC}$ & High intensity cropping & $\mathrm{XOX}$ & Xanthine oxidase \\
\hline LIC & Low intensity cropping & PBS & Phosphate buffered saline \\
\hline LCMS/MS & $\begin{array}{l}\text { Liquid chromatography-mass } \\
\text { spectrometry / mass } \\
\text { spectrometry }\end{array}$ & $\mathrm{NaCl}$ & Sodium chloride \\
\hline $\mathrm{GC}$ & Gas chromatography & NP40 & $\begin{array}{l}\text { Tergitol-type NP-40 } \\
\text { (nonylphenoxypolyethoxylethanol) }\end{array}$ \\
\hline $\begin{array}{l}\text { EPA3540C and } \\
\text { EPA8081A } \\
\text { procedures }\end{array}$ & $\begin{array}{l}\text { Environmental Protection } \\
\text { Agency methods 3540C and } \\
\text { 8081A; followed by SGS } \\
\text { India Pvt. Ltd. }\end{array}$ & EDTA & Ethylenediaminetetraacetic acid \\
\hline $\mathrm{OP}$ & Organophosphorus pesticide & SDS-PAGE & $\begin{array}{l}\text { Sodium dodecyl } \\
\text { sulfate-Polyacrylamide } \\
\text { gel electrophoresis }\end{array}$ \\
\hline $\mathrm{EC}$ & Effective Concentration & PVDF & Polyvinylidenedifluoride \\
\hline SP & Synthetic pyrethroid & HRP & Horseradish peroxidase \\
\hline ES & Endosulfan pesticide & DTPA & Diethylene triamine pentaacetic acid \\
\hline $\begin{array}{l}\text { Experimental } \\
\text { treatments }\end{array}$ & $\begin{array}{l}\text { D0 (control) } \\
\text { D1 }(5 \% \mathrm{OP}+1.5 \% \mathrm{SP}+ \\
5.5 \% \mathrm{ES}) \\
\mathrm{D} 2(12.5 \% \mathrm{OP}+4 \% \mathrm{SP}+ \\
15 \% \mathrm{ES}) \\
\mathrm{D} 3(20 \% \mathrm{OP}+6.5 \% \mathrm{SP}+ \\
23.5 \% \mathrm{ES}) \\
\mathrm{D} 4(25 \% \mathrm{OP}+8 \% \mathrm{SP}+ \\
29 \% \mathrm{ES}) \\
\mathrm{D} 5(30 \% \mathrm{OP}+10 \% \mathrm{SP}+ \\
35 \% \mathrm{ES})\end{array}$ & Tris- $\mathrm{HCl}$ & $\begin{array}{l}\text { Tris (2-Amino-2-hydroxymethyl- } \\
\text { propane-1,3-diol)-Hydrochloric } \\
\text { acid }\end{array}$ \\
\hline SOD & Superoxide dismutase & CAT & Catalase \\
\hline
\end{tabular}

Stress oxydatif provoqué par des pesticides sur des populations indigènes d'abeilles, élevées en laboratoire et en champ, dans des zones d'agriculture intensive de deux Etats de l'est de l'Inde

Apis cerana / Apis dorsata/ enzyme / dismutase / catalase / oxydase / insecticide

Durch Pestizide verursachter oxydativer Stress bei Labor. und Feldpopulationen einheimischer Honigbeienen entlang zweier intensiver Agrarlandschaften in zwei ostindischen Staaten

Apis cerana / Apis dorsata / Enzyme / SuperoxidDismutase / Xanthin-Oxidase / Katalase / Insektizid

\section{REFERENCES}

Abrol, D.P. (2011) Foraging. In: Hepburn, H.R., Radloff, S.E. (eds.) Honeybees of Asia, pp. 257-292. Springer, New York

Aebi, H. (1984) Catalase, in : Packer, L. (Ed.), Methods in Enzymology. Academic Press, Orlando, pp. 121126. Agricultural census, Government of India (http://agcensus.nic.in/).

Ahmad, S., Duval, D.L., Weinhold, L.C., Pardini, R.S. (1991) Cabbage looper antioxidant enzymes: tissue specificity. Insect Biochem. 21(5), 563-572 
Akhgari, M., Abdollahi, M., Kebryaeezadeh, A., Hosseini, R., Sabzevari, O. (2003) Biochemical evidence for free radicalinduced lipid peroxidation as a mechanism for subchronic toxicity of malathion in blood and liver of rats. Hum. Exp. Toxicol. 22, 205-211

Anderson, A.D., Patton, R.L. (1955) In vitro studies of uric acid synthesis in insects. J. Exp. Zool. 128(3), 443-451

Aranda, R., Doménech, E., Rus, A.D., Real, J.T., Sastre, J., Viña, J., Pallardó, F.V. (2007) Age-related increase in xanthine oxidase activity in human plasma and rat tissues. Free Radic. Res. 41(11), 1195-1200

Barbeta, C., Lino-Neto, T., Piques, M.C., Sousa, M.F., Tavares, R.M., Pais, M.S. (2004) Identification of Zantedeschia aethiopica Cat1 and Cat2 catalase genes and their expression analysis during spathe senescence and regreening. Plant Sci. 167, 889-898

Archer, C.R., Pirk, C.W.W., Wright, G.A., Nicolson, S.W. (2014) Nutrition affects survival in African honeybees exposed to interacting stressors. Funct. Ecol. . doi:10.1111/1365-2435.12226

Bouayed, J., Bohn, T. (2010) Exogenous antioxidants - double-edged swords in cellular redox state: Health beneficial effects at physiologic doses versus deleterious effects at high doses. Oxidative. Med. Cell Longev. 3, 228-237

Badiou-Bénéteau, A., Carvalho, S.M., Brunet, J.-L., Carvalho, G.A., Buleté, A., Giroud, B., Belzunces, L.P. (2012) Development of biomarkers of exposure to xenobiotics in the honey bee Apis mellifera: application to the systemic insecticide thiamethoxam. Ecotoxicol. Environ. Saf. 82, 22-31

Bradford, M.M. (1976) A rapid and sensitive method for the quantitation of microgram quantities of protein utilizing the principle of protein-dye binding. Anal. Biochem. 72, 248-254

Brittain, C.A., Vighi, M., Bommarco, R., Settele, J., Potts, S.G. (2010) Impacts of a pesticide on pollinator species richness at different spatial scales. Basic Appl. Ecol. 11, 106-115

Choudhary, A., Sharma, D.C., Badiyala, A. (2009) Relative safety of some pesticides against honey bees, Apis cerana cerana Fab. and Apis mellifera L. on mustard (Brassica Juncea L. Czern). Pestic. Res. J. 21(1), 67-70

Claudianos, C., Ranson, H., Johnson, R.M., Biswas, S., Schuler, M.A., Berenbaum, M.R., Eyereisen, R., Oakeshott, J.G. (2006) A deficit of detoxification enzymes: pesticide sensitivity and environmental response in the honeybee. Insect Mol. Biol. 15(5), 615-636

Conners, D.E. (2004) Biomarkers of oxidative stress in freshwater clams (Corbicula fluminea), as mechanistic tools to evaluate the impairment of stream ecosystem health by lawn care pesticides. Ph. D. Thesis, Graduate Faculty, University of Georgia, Georgia.

Cresswell, J.E., Laycock, I. (2012) Towards the comparative ecotoxicology of bees: the response-response relationship. Julius-Kuhn-Archiv 437

Czarniewska, E., Kasprzyk, A., Ziemnicki, K. (2003) Effect of paraquat and metoxychlor on antioxidant enzymes in frog Rana esculenta L liver. Biol. Lett. 40(2), 125-133

Decourtye, A., Armengaud, C., Renou, M., Devillers, J., Cluzeau, S. (2005) Comparative sublethal toxicity of nine pesticides on olfactory learning performances of the honeybee Apis mellifera. Arch. Environ. Contam. Toxicol. 48, 242-250

Decourtye, A., Armengaud, C., Renou, M., Devillers, J., Cluzeau, S. (2004) Imidacloprid impairs memory and brain metabolism in the honeybee (Apismellifera L.). Pestic. Biochem. Phys. 78, 83-92

Desneux, N., Decourtye, A., Delpuech, J.M. (2007) The sublethal effects of pesticides on beneficial arthropods. Annu. Rev. Entomol. 52, 81-106

Devillers, J., Pham-Delegue, M.H., Decourtye, A., Budzinski, H., Cluzeau, S., Maurin, G. (2002) Structure-toxicity modeling of pesticides to honey bees. Environ. Res. 13(7-8), 641-648

Dhaliwai, H.S., Sharma, P.L. (1974) Foraging range of the Indian honeybee. J. Apic. Res. 13, 137-141

Dyer, F.C., Seeley, T.D. (1991) Dance dialects and foraging range in three Asian honey bee species. Behav. Ecol. Sociobiol. 28, 227-233

Felton, G.W., Summers, C.B. (1995) Antioxidant systems in insects. Arch. Insect Bioch. Physiol. 29(2), 187-197

Fridovich, I. (1982) Superoxide dismutase in biology and medicine. In: Autor, A.P. (ed.) Pathology of Oxygen, pp. 1-19. Academic, New York

Fujiyuki, T., Matsuzaka, E., Nakaoka, T., Takeuchi, H., Wakamoto, A., Ohka, S., Sekimizu, K., Nomoto, A., Kubo, T. (2009) Distribution of Kakugo virus and its effects on the gene expression profile in the brain of the worker honeybee Apis mellifera L. J. Virol. 83(22), 11560

George, P.J.E., Ambrose, D.P. (2004) Toxic effects of insecticides in the histomorphology of alimentary canal, testis and ovary in a reduviid Rhynocoris kumarii Ambrose and Livingstone (Hemiptera: Reduviidae). J. Adv. Zool. 25, 46-50

Gilbert, M.D., Wilkinson, C.F. (1974) Microsomal oxidases in honey bee, Apis mellifera (L.). Pestic. Biochem. Physiol. 4(1), 56-66

Halliwell, B. (2007) Biochemistry of oxidative stress. Biochem. Soc. Trans. 35(Pt 5), 1147-1150

Han, P., Niu, C.-Y., Lei, C.-L., Cui, J.-J., Desneux, N. (2010) Use of an innovative T-tube maze assay and the proboscis extension response assay 
to assess sublethal effects of GM products and pesticides on learning capacity of the honey bee Apis mellifera L. Ecotoxicology 19(8), 16121619

Hardstone, M.C., Scott, J.G. (2010) Is Apis mellifera more sensitive to insecticides than other insects. Pest Manag. Sci. 66(11), 1171-1180

Harrison, R. (2002) Structure and function of xanthine oxidoreductase: where are we now? Free Radic. Biol. Med. 33(6), 774-797

Hayashi, Y. (1961) Properties of xanthine dehydrogenase in the silkworm, Bombyx mori L. Nature 192, 756757

Henry, N., Béguin, M., Requier, F., Rollin, O., Odoux, J.-F., Aupinel, P., Aptel, J., Tchamitchian, S., Decourtye, A. (2012) A common pesticide decreases foraging success and survival in honey bees. Science 336(6079), 348-350

Hille, R., Nishino, T. (1995) Flavoprotein structure and mechanism. 4. Xanthine oxidase and xanthine dehydrogenase. FASEB J. 9(11), 995-1003

Idris, A.B., Grafius, E. (1993) Pesticides affect immature stages of Diadegma insulare (Hymenoptera, Ichneumonidae) and its host, the diamondback moth (Lepidoptera, Plutellidae). J. Econ. Entomol. 86, 1203-1212

Irzykiewicz, H. (1955) Xanthine oxidase of the clothes moth, Tineola bisselliella, and some other insects. Aust. J. Biol. Sci. 8, 369-377

Joanisse, D.R., Storey, K.B. (1996) Oxidative stress and antioxidants in overwintering larvae of cold-hardy goldenrod gall insects. J. Exp. Biol. 199(Pt 7), 1483-1491

Johnson, R.M., Ellis, M.D., Mullin, C., Frazier, M. (2010) Pesticides and honey bee toxicity - USA. Apidologie 41(3), 312-331

Khessiba, A., Roméo, M., Aïssa, P. (2005) Effects of some environmental parameters on catalase activity measured in the mussel (Mytilus galloprovincialis) exposed to lindane. Environ. Pollut. 133(2), 275-281

Klein, J.P., Moeschberger, M.L. (2003) Survival Analysis. Techniques for Censored and Truncated Data, 2nd edn. Springer Publishers, New York

Koeniger, N., Vorwohl, G. (1979) Competition for food among four sympatric species of Apini in Sri Lanka (A. dorsata, A. cerana, A. florea and Trigona iridipennis). J. Apic. Res. 18, 95-109

Koetz, A.H. (2013) Ecology, behaviour and control of Apis cerana with a focus on relevance to the Australian incursion. Insects 4, 558-592

Krupke, C.H., Hunt, G.J., Eitzer, B.D., Andino, G., Given, K. (2012) Multiple routes of pesticide exposure for honey bees living near agricultural fields. PLoS One 7(1), e29268

Landa, V., Sula, J., Marec, F., Matha, V., Soldan, T. (1991) Methods for Assessing Exposure of insects. In: Tardiffand, R.G., Goldstei, B. (eds.) Human and
Non-Human Biota, pp. 249-266. John Wiley and Sons Ltd., New York

Mamidala, P., Jones, S.C., Mittapalli, O. (2011) Metabolic resistance in bed bugs. Insects 2(1), 36-48

Marklund, S., Marklund, G. (1974) Involvement of the superoxide anion radical in the autoxidation of pyrogallol and a convenient assay for superoxide dismutase. Eur. J. Biochem. 47(3), 469-474

McCord, J.M., Fridovich, I. (1969) Superoxide dismutase: an enzymic function for erythrocuprein (heinocuprein). J. Biol. Chem. 244(22), 6049-6055

Medina, P., Budia, F., Del Estal, P., Vinuela, E. (2004) Influence of azadirachtin, a botanical insecticide, on Chrysoperla carnea (Stephens) reproduction: toxicity and ultrastructural approach. J. Econ. Entomol. 97, 43-50

Meneshian, A., Bulkley, G.B. (2002) The physiology of endothelial xanthine oxidase: from urate catabolism to reperfusion injury to inflammatory signal transduction. Microcirculation 9(3), 161-175

Mueller, S., Riedel, H.-D., Stremmel, W. (1997) Direct evidence for catalase as the predominant $\mathrm{H}_{2} \mathrm{O}_{2}$ removing enzyme in human erythrocytes. Blood 90(12), 4973-4978

Mullin, C.A., Frazier, M., Frazier, J.L., Ashcraft, S., Simonds, R., vanEngelsdorp, D., Pettis, J.S. (2010) High levels of miticides and agrochemicals in North American apiaries: implications for honey bee health. PLoS One 5(3), e9754

Nishida, Y. (2011) The chemical process of oxidative stress by copper (II) and iron (III) ions in several neurodegenerative disorders. Monatsh. Chem. 142, 375-384

Nishino, T., Okamoto, K., Kawaguchi, Y., Hori, H., Matsumura, T., Eger, B.T., Pai, E.F., Nishino, T. (2005) Mechanism of the conversion of xanthine dehydrogenase to xanthine oxidase: identification of the two cysteine disulfide bonds and crystal structure of a non-convertible rat liver xanthine dehydrogenase mutant. J. Biol. Chem. 280(26), 2488824894

Osborne, J.L. (2012) Bumble bees and pesticides. Nature 491(7422), 43-45

Palmer, M.J., Moffat, C., Saranzewa, N., Harvey, J., Wright, G.A., Connolly, C.N. (2013) Cholinergic pesticides cause mushroom body neuronal inactivation in honeybees. Nat. Commun. 4, 1634

Partap, U. (2011) The Pollination Role of Honeybees. In: Hepburn, H.R., Radloff, S.E. (eds.) Honeybees of Asia, pp. 227-255. Springer-Verlag Berlin, Heidelberg

Qiao, D., Seidler, F.J., Slotkin, T.A. (2005) Oxidative mechanisms contributing to the developmental neurotoxicity of nicotine and chlorpyrifos. Toxicol. Appl. Pharm. 206(1), 17-26

Ranjbar, A., Solhi, H., Mashayekhi, F.J., Susanabdi, A., Rezaie, A., Abdollahi, M. (2005) Oxidative stress in acute human poisoning with organophosphorus 
insecticides; a case control study. Environ. Toxicol. Pharmacol. 20(1), 88-91

Schreinemachers, P., Tipraqsa, P. (2012) Agricultural pesticides and land use intensification in high, middle and low income countries. Food Policy 37(6), 616-626

Schriever, C.A., Callaghan, A., Biggs, J.P., Liess, M. (2008) Freshwater Biological Indicator of Pesticide Contamination. Environment Agency, Rio House

Smirle, M.J., Winston, M.L. (1988) Detoxifying enzyme activity in worker honeybees: an adaptation for foraging in contaminated ecosystems. Can. J. Zool. 66(9), 1938-1942

Smirle, M.J. (1988) Insecticide resistance mechanism in the honey bee, Apis mellifera L. Ph.D. Thesis, Graduate Faculty, Simon Fraser University, Vancouver.

Stanley, J., Chandrasekaran, S., Preetha, G., Kuttalam, S. (2010) Toxicity of diafenthiuron to honey bees in laboratory, semi-field and field conditions. Pest Manag. Sci. 66(5), 505-510

Starr, C.K., Schmidt, P.J., Schmidt, J.O. (1987) Nest-site preference of the giant honey bee, Apis dorsata (Hymenoptera : Apidae), in Borneo. Pan-Pac. Entomol. 63(1), 37-42

Stefanidou, M., Athanaselis, S., Koutselinis, A. (2003) The toxicology of honey bee poisoning. Vet. Hum. Toxicol. 45(5), 261-265

Visser, A., Blacquière, T. (2010) Survival rate of honeybee (Apis mellifera) workers after exposure to sublethal concentrations of imidacloprid. Proc Neth. Entomol. Soc. Meet. 21

Velki, M., Kodrík, D., Večeřa, J., Hackenberger, B.K., Socha, R. (2011) Oxidative stress elicited by insecticides: a role for the adipokinetic hormone. Gen. Comp. Endocrinol. 172(1), 77-84

Villa, S., Vighi, M., Finizio, A., Serini, G.B. (2000) Risk assessment for honeybees from pesticide-exposed pollen. Ecotoxicology 9, 287-297

Vorbach, C., Harrison, R., Capecchi, M.R. (2003) Xanthine oxidoreductase is central to the evolution and function of the innate immune system. Trends Immunol. 24(9), 512-517

Wajner, M., Harkness, R.A. (1989) Distribution of xanthine dehydrogenase and oxidase activities in human and rabbit tissues. Biochim. Biophys. Acta 991(1), 79-84

Welinder, C., Ekblad, L. (2011) Coomassie staining as loading control in western blot analysis. J. Proteome Res. 10(3), 1416-1419

Whitehorn, P.R., O'Connor, S., Wackers, F.L., Goulson, D. (2012) Neonicotinoid pesticide reduces bumble bee colony growth and queen production. Science 336(6079), 351-352

Winfree, R., Aguilar, R., Vázquez, D.P., LeBuhn, G., Aizen, M.A. (2009) A meta-analysis of bees' responses to anthropogenic disturbance. Ecology 90(8), 2068-2076

Yu, S.J., Robinson, F.A., Nation, J.L. (1984) Detoxification capacity in the honey bee, Apis mellifera L. Pestic. Biochem. Physiol. 22, 360368

Zhang, J.-W., Lv, G.-C., Zhao, Y. (2010) The significance of the measurement of serum xanthine oxidase and oxidation markers in patients with acute organophosphorus pesticide poisoning. J. Int. Med. Res. 38(2), 458-465 